九州大学学術情報リポジトリ

Kyushu University Institutional Repository

\title{
THE FAMILY ANTHRIBIDAE OF JAPAN (COLEOPTERA). PART 4
}

Morimoto, Katsura

Entomological Laboratory, Faculty of Agriculture, Kyushu University

https://doi.org/10.5109/2414

出版情報: ESAKIA. 17，pp.53-107，1981-11-30. Entomological Laboratory，Faculty of Agriculture， Kyushu University

バージョン :

権利関係 : 


\title{
THE FAMILY ANTHRIBIDAE OF JAPAN (COLEOPTERA). PART 4*
}

\author{
Katsura Morimoto \\ Entomological Laboratory, Faculty of Agriculture, \\ Kyushu University, Fukuoka 812, Japan
}

\begin{abstract}
This is the fourth part of the revision of Japanese Anthribidae, treating the tribes Zygaenodini and Corrhecerini (=Nessiarini). New taxa, recombinations and synonymies treated in this paper are as follows:

Noxius japonicus sp. nov.

Autotropis okinawanus sp. nov.

Uncifer akashii sp. nov.

Unciferina gen. nov.. japonica sp. nov. (Type-species) ; brevifrons sp. nov. ; persimilis sp. nov.

Rhaphitropis nigromaculatus sp. nov. ; truncatoides sp. nov. ; niger sp. nov. ; iriei sp. nov. ; flavipes sp. nov.

Gibber brevirostris (Sharp, 1891), comb. nov. (D issoleucas)

Gibber incisus (Sharp), comb. nov. (Directarius)

Gibber nodulosus (Sharp, 1891), comb. nov. (Dissoleucas)

Gibber ogasaw arensis sp. nov.

Phaulimia angusta sp. nov. ; annulipes sp. nov. ; rufobasis sp. nov.

Phaulimia confinis (Sharp, 1891). comb. nov. (Ulorhinus)

Phaulimia aberrans (Sharp, 1891), comb. nov. (Ulorhinus)

Ulorhinus gokani sp. nov.

Habrissus analis sp. nov. ; nigronotatus sp. nov.

Habrissus pardalis (Sharp, 1891), comb. nov. (Tropideres)

Habrissus unciferoides (Nakane, 1963), comb. nov. (Hypseus)

Habrissus formosanus Jordan, 1912, status nov. (ssp. of longipes)

Habrissus cylindricus (Sharp, 1891), comb. nov. (Tropideres)

Rhaphitropis concolor (Sharp, 1891) is a new synonym of guttifer (Sharp, 1891).

Ulorhinus germanus Jordan, 1928, is a new synonym of confinis (Sharp, 1891).

Nerthomma aplota Jordan, 1912, and Habrissus formosanus Jordan, 1912, are recorded from Japan for the first time.
\end{abstract}

\section{Tribe Zygaenodini}

Zygénodides Lacordaire, Gen. Col., VII: 542, 1866.

Zygaenodini Morimoto, Bull. Gov. Forest Exp. Sta., (246) : 43, 1972.

* Contribution from the Entomological Laboratory, Faculty of Agriculture, Kyushu University, Fukuoka (Ser. 3, No. 94). 
Noxius Jordan

Noxius Jordan, Nov. Zool., XXXIX: 328, 1936 (n. n. pro Blaberus Sch., nec AudientServille, 1831)

Blaberus Schoenherr, Gen. Sp. Curc., V: 248, 1839 (Type-species: Blaberus fallax Fahraeus, 1839, by original designation) ; Imhoff, Sing. Gen. Curc., Heft 8, Nr. 66,1842; Lacordaire, Gen. Col., VII: 584, 1866; Jordan, Voy. All. et Jean. Afr. or., Col.I, x: 336, 1914.

The generic position of the following new species is followed after Jordan (1914).

\section{Noxius japonicus sp. nov.}

(Fig. 1)

Male and female. Black, anterior margin of rostrum and labrum dark reddish brown, tarsi often brownish black; densely with brownish black and whitish scales, the latter forming following patches : head sparsely and evenly whitish, often the scales denser around eyes, pronotum with anterior and posterior margins with fasciae, and with a median and a pair of lateral stripes, which are interrupted in the middle and median stripe often absent before the middle; scutellum whitish ; elytra with four scaly bands, the basal band usually absent on second to fourth intervals, antemedian band widening laterally, postmedian band often interrupted on first and/or fourth intervals, anteapical band short and narrow, usually on third to seventh intervals, often vestigial, or often extending posteriorly to the whitish apical margin; underside whitish, scales denser on lateral margins of thorax and sparser and finer on the median area and on abdomen.

Head evenly convex, forehead between eyes a little narrower than the base of rostrum. Eyes latero-dorsal, convex, emarginate. Rostrum transverse, slightly dilated apically. Antennae short, first and second segments globular, club compact.

Pronotum transverse (4:3), evenly convex, reticulately provided with small punctures, each puncture bearing a brownish black fine hair excepting the scaled area ; transverse carina trisinuate posteriorly, semicircularly rounded at sides, lateral carinae short, carinulae absent.

Scutellum as long as wide, small, densely covered with whitish scales.

Elytra parallel-sided, the conjoint basal margin evenly and weakly concave, first interval a little narrower than second, subbasal swellings weak on second to fifth intervals, where the whitish scales absent.

Pygidium as long as wide, straightly narrowing posteriorly and widely rounded at apex, densely punctate, sparsely with whitish scales.

Legs robust. Femora clavate. sulcate beneath on exterior half for the 
reception of tibiae. Tibiae straight, without any scaly ring. Tarsi with first segment as long as second and third combined, claws dentate.

Venter flattened or slightly depressed in the middle, fifth ventrite producing ventrad on posterior half in male; in female, venter not flattened, fifth ventrite scarcely producing ventrad; with first to fourth ventrites short medially, first ventrite behind coxa as long as second, finely and rugosely punctate.

Length :1.5-2. $3 \mathrm{~mm}$ (excl. head).

Holotype o (Type No. 2296, Kyushu Univ.), Mt. Urabu, Yonaguni Is., 15. vi. $1974, \mathrm{H}$. Irie leg.

Paratypes: Same data as holotype, $4 \lesssim 4$ ㅇ․ Mt. Banna, Ishigaki Is., $1 \precsim$, 3. $v$. 1969, H. Makihara leg. Cape Sata, Kagoshima Pref., 1ㅇ, 7. vi. 1959, J. Nagao leg.

Distributron : Japan (Kyushu, Ishigaki and Yonaguni Isls.).

This small and cylindrical new species is similar to curtirostris (Rey, 1860) from Europe, but the forehead is narrower than the base of rostrum and the
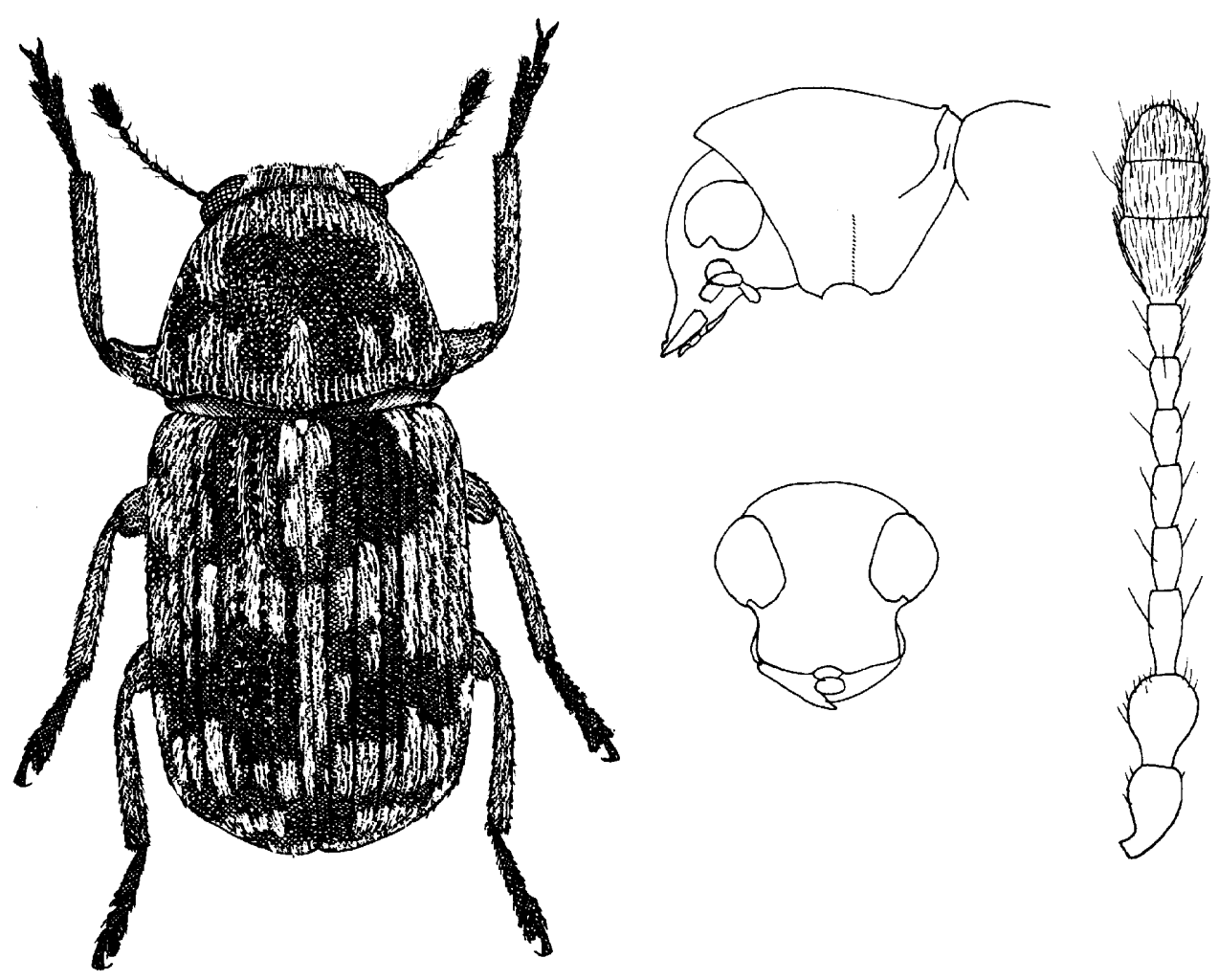

Fig. 1. Noxius japonicus sp. nov., male. 
scaly pattern is different.

\section{Nerthomma Pascoe}

Nerthomma Pascoe, Ann. Mag. Nat. Hist., (3) V: 42, 1860 (Type-species: Nerthomma sticticum Pascoe, by monotypy).

\section{Nerthomma aplota Jordan}

(Photo A)

Nerthomma aplota Jordan, Nov. Zool., XXX: 142, 1912 (Taiwan : Fuhosho and Kosempo) ; Jordan, Nov. Zool., XXXIV: 93, 1928 (Tonkin).

Specimens examined: Nishinakama, Amami-Oshima, $1 \precsim$, 1-7. vi. 1970, H. Makihara leg. Rimogan-Magan, Taiwan, $1 \gtrsim$, 10. vii. 1961, T. Shirôzu leg. Lushan Wenchuan, Nantou Hsien, Taiwan, 1ð1ㅇ, 6. vi. 1976, H. Makihara leg. ; 1 , 27-29. v. 1980, H. Makihara leg. Penpuchi, Nantou Hsien, Taiwan, 1 우, 9. vii. 1966, H. Sasaji leg. Tsuifeng, Nantou Hsien, Taiwan, 1Љ, 10. vii. 1966, H. Sasaji leg.

Distribution : Japan (Amami-Oshima)-new record, Taiwan, Tonkin.

\section{Autotropis Jordan}

Autotropis Jordan, Nov. Zool., XXI: 241, 1924 (Type-species. Autotropis modesta Jordan, by original designation).

\section{Autotropis basipennis (Sharp)}

(Photos C, D)

Tropideres basipennis Sharp, Trans. Ent. Soc. London,: 301, 1891 (Kurigahara).

Autotropis basipennis : Wolfrum, Ent. Blätt., 41-44: 141, 1948.

Specimens examined : Mt. Kiyosumi, Chiba Pref., 1 ex., 9. vi. 1963, K. Morimoto leg. Hikawa, Okutama, Tokyo Pref., 2 exs., 2. v. 1977, and 1 ex., 13 v. 1977, A. Yamagami leg. reared from dead trunk of Zelkova serrata. Tanbayamamura, Yamanashi Pref., 1 ex., 28. iv. 1977, A. Yamagami leg. reared from Zelkova serrata. Mt. Kumado, Fukuoka Pref., 1 ex., 24. vii. 1957, H. Ishibashi leg. ; 1 ex., 3. viii. 1959, Y. Miyake leg.; 1 ex., 2. viii. 1958, J. Nagao leg.

Distribution : Japan (Honshu, Kyushu), Siberia (Wladiwostock).

\section{Autotropis distinguendus (Sharp)}

(Fig. 2, A)

Tropideres distinguendus Sharp, Trans. Ent. Soc. London, : 310, 1891 (Nagasaki, Kiga, Miyanoshita, Yokohama, Junsai) ; Iga, Col. Ill. Ins. Jap., Col. : 137, pl. 49, fig. 11, 1955; Iga, 1. c., revised ed. : 195, pl. 61, fig. 1348, 1956. 
Autotropis distinguendus: Morimoto, Sci. Bull. Fac. Agr. Kyushu Univ., 19 : 162, 1962 ; Nakane, Icon. Ins. Jap. col. nat. ed., II: 352, pl. 176, fig. 22, 1963 ; Iga, Col. Ill. Ins. Jap., Col. rev. ed. : 195, pl. 61, fig. 1348, 1977.

Specimens examined : 94 examples from Hokkaido (Sapporo, Kumaishi-cho, Yakumo-cho, Ashoro), Aomori Pref. (Towada, Kodomari-son), Fukushima Pref. (Hinoemata, Yunohana), Gunma Pref. (Mt. Hotakayama), Ibaraki Pref. (Furukawa), Chiba Pref. (Mt. Nokogiri), Nagano Pref. (Ina, Tobira spa), Kyoto Pref. (Hanasetoge), Niigata Pref. (Murakami), Kochi Pref. (Kitagawa), Fukuoka Pref. (Mt. Hiko, Mt. Wakasugi, Hirao, Mt. Fukuchi), Kumamoto Pref. (Kurokami, Kikuchi-suigen, Tatsudayama), Oita Pref. (Mt. Sobo), Miyazaki Pref. (Ookochi), Kagoshima Pref. (Shiroyama, Terayama), Tsushima (Sasuna, Ohoshiyama), and Shimokoshiki Is. (Mt. Aoshiodake).

Distribution : Japan (Hokkaido, Honshu, Shikoku, Kyushu, Tsushima, Shimokoshiki Is.).

\section{Autotropis okinawanus sp. nov.}

(Fig. 2, B; Photo B)

Male and female. Black, light-pubescent part of upperside rufescent, antennae and legs excepting darker median parts of femora reddish brown; dorsal surface variegated with greyish, brownish and blackish pubescence,
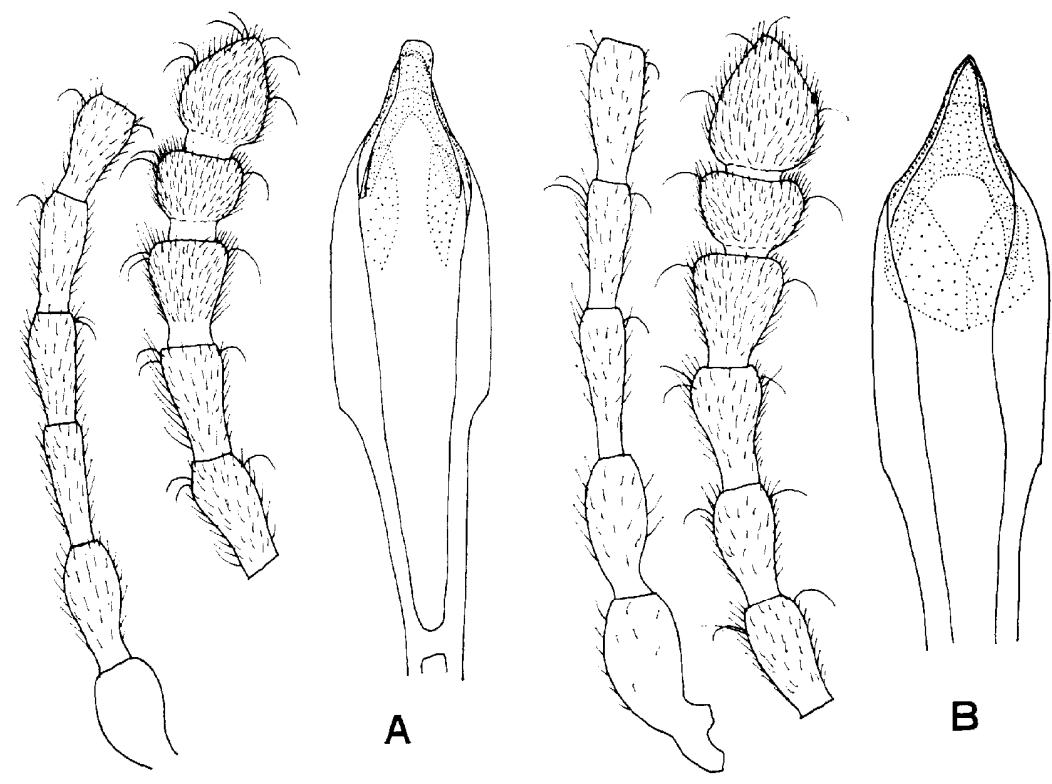

Fig. 2. Autotropis spp., antennae and penes. A: distinguensus (Sharp). B: okinawanus sp. nov. 
pronotum mottled with small black patches, greyish pubescence forming three longitudinal median short patches and a pair of lateral patches, the latter often indistinct; elytra with a V-shaped basal black mark between third striae, the mark often separated into three spots or reduced to form a pair of spots, the side margins from shoulder to apex blackish, the streak posteriorly widened dorsad as a triangular expansion at posterior third as far as second stria, suture with a few small black spots; underside evenly covered with greyish hairs.

Head and rostrum densely punctate, forehead between eyes a little narrower than the base of rostrum $(5: 8)$, rostrum transverse, flat with a median carina on basal three-fourths. Antennae reaching the posterior margin of pronotum in male, a little shorter and not exceeding the dorsal carina of pronotum in female, third and fourth segments slender, third to eighth segments each successively broader.

Pronotum transverse $(7: 6)$, the sides evenly rounded, disk convex, reticulately with small punctures, without median carina, dorsal transverse carina almost straight in the middle and slightly curved posteriorly from the middle of elytron outwards, widely rounded and continued to lateral carina, which being not extending to the middle, basal carinulae transverse, almost touching the lateral end of dorsal carina, longitudinal carinulae absent.

Scutellum a little longer than wide, greyish.

Elytra cylindrical, 7/10 times as wide as long, basal margin strongly convex anteriorly, transversely depressed behind subapical swellings.

Pygidium semicircular in shape, Mesosternal process truncate.

Length : 3.1-4.0 mm (excl. head).

Holotype ㅇ (Type No. 2297, Kyushu Univ.), Yona, Okinawa, 2. vi. 1975, H. Irie leg.

Paratypes: Same locality as holotype, 1우 19. x. 1973, S. Miyamoto leg. ; 1 우, 15. vii. 1970, H. Makihara leg.;1 f, 18. v. 1978, H. Makihara leg. Oku, Okinawa, 1 9 ㅇ, 15-17. v. 1978, H. Makihara leg. ; 3 우,16. v. 1976, T. Ogasawara leg. ; 1 우, 4. iv. 1979, H. Makihara leg. Mt. Yonahadake, Okinawa, $2 \jmath^{\Uparrow} 1$ ㅇ, 17. iv. 1974, H. Irie leg. ; 1 우 1. vi. 1974, H. Irie leg. Higa, Kumejima, 1 후, 22. iii. 1977, Y. Hori leg. Izumi, Okinawa, $2 \sigma^{7}$, 21. x. 1963, S. Miyamoto and S. Uéno leg. Hatsuno, Amami-Oshima, 1 $\sigma^{\wedge}, 2$. iv. 1972, H. Irie leg. Nase, Amami-Oshima, 1ㅇ, 9. iv. 1974, H. Irie leg. Nishinakama, Amami-Oshima, 1 ㅇ, 25. v. 1978, H. Makihara leg. Shinmura, Amami-Oshima, 1 § 1 \& , 26. iv-5. v. 1967, H. Takizawa leg.

Distribution: Japan (Amami-Oshima, Okinawa and Kumejima Isls.).

This new species is very close to distinguendus (Sharp) and modestus Jordan, but can be separable from them by the characters noted in the following key. 
Key to species of the genus Autotropis fROM JaPAN

1: Elytra each with profound transverse depression at the base, which being elevated in front of the depression and projecting on the base of pronotum; legs with apical half of tibiae, apical area of the first segment of tarsi and second segment of tarsi blackish; elytra with two broad blackish bands, the basal band interrupted on the base of fifth interval, the median one often mixed with several small brown spots on fifth and seventh intervals...........

Autotropis basipennis (Sharp)

1': Elytra weakly depressed transversely at the base; tibiae and tarsiconcolorous; basal mark of elytra V-shaped in general

2: Elytra without subapical transverse depression, so that the surface evenly rounded to apex (Philippines, Sumatra, Tonkin).......... (Autotropis modestus Jordan)

2': Elytra with weak transverse depression behind subapical swellings ...................... 3

3: Elytra with a postmedian black band between fifth intervals; aedeagus with the dorsal plate of penis rounded at tip, the ventral plate narrowly rounded at tip ................................................ Autotropis distinguendus

3': Elytra with the blackish lateral streak posteriorly widened dorsad as a triangular expansion at posterior third as far as second stria, subapical transverse depression stronger; aedeagus with the dorsal and ventral plates of penis sharply pointed at apex

Autotropis okinawanus sp. nov.

\section{Uncifer Jordan}

Uncifer Jordan, Ann. Mus. Genova, (3)1: 88, 1904 (Type-species: Uncifer sticticus Jordan, by monotypy) ; Jordan, Ann. Mag. Nat. Hist., (9)XVI: 259, 1925; Morimoto, Bull. Gov. Forest Exp. Sta., (246) : 44, 78, 1972.

\section{Uncifer pectoralis (Sharp)}

(Figs. 3, A; 4, M, N; Photo E)

Tropideres pectoralis Sharp, Trans. Ent. Soc. London, : 315, 1891 (Kashiwagi, Kurigahara, Nikko, Junsai)

Uncifer pectoralis : Morimoto, Sci. Bull. Fac. Agr. Kyushu Univ., 19: 164, 1962; Nakane, Icon. Ins. Jap. col. nat. ed., II: 351, pl. 175, fig. 10, 1963.

SPectmens examined: Namarigawa, Yakumo-cho, Hokkaido, $1 \delta^{1} 1$, 5. viii. 1976, H. Irie leg. Jushichinosawa, Mt. Nipesotsu, Hokkaido, 1우, 17. vii. 1976, H. Irie leg, Marunuma, Gunma Pref., 1\%, 9. vii. 1975, H. Irie leg. Hakone, Kanagawa Pref., 1 o , 26. iv. 1961, K. Morimoto leg. Uchinokaya, Ina, Nagano Pref,, lg, 26. vii. 1962, K. Oshima leg. Mt. Tebako, Kochi Pref., 1우, 7. viii. 1957, K. Morimoto leg. Makiyama, Kochi Pref., 1ㅇ, 13. vi. 1954, K. Kojima leg. Mt. Fukuchi, Fukuoka Pref., 1 ㅇ, 19. vi. 1969, H. Makihara leg. Mt. Inunaki, Fukuoka Pref., 1 우, 29. vi. 1959, J. Nagao leg. ;1우, 10. vi. 1960, J. Nagao leg. Mt. Hiko, Fukuoka Pref., $1 \gtrsim$, 9. v. 1957, K. Morimoto leg. Mt. Kumado, Yame, Fukuoka Pref., 1 우, 3. viii. 1954, Y. Miyake leg. Mt. Shakadake, Yame, Fukuoka Pref., $1 \Im^{\star}, 5$. vii. 1961, H. Ishibashi leg. Mt. Daisen, Kuju, Oita Pref., $2 \precsim 1$ 우, 19. vii. 1978, K. Morimoto leg. Mt. Shiroiwa, Miyazaki Pref., 1 우 , 26. 
vii. 1974, H. Trie leg. Yuyama-toge, Miyazaki Pref., 2 우, 29. v. 1971, H. Makihara leg. Mt. Takachiho, Kirishima, Kagoshima Pref., 2 ?, 13. vii. 1955, H. Maebara leg.

Distribution : Japan (Hokkaido, Honshu, Shikoku, Kyushu).

This species is easily recognized by the shape of mesosternal process. The dorsal carina of pronotum is straightly converging internally and narrowly rounded in the middle. The head excepting vertex and rostrum is densely covered with white hairs in male, while in female the head and rostrum are covered with sparse brown pubescence and with a median greyish stripe on forehead.

The paratype taken at Nikko by Lewis (in Brit. Mus. N. H.) is a female of truncatus.

\section{Uncifer akashii sp. nov.}

(Figs. 4, H-J)

Male. Brown, pronotum, head and rostrum a little darker, sparsely with greyish pubescence at side margins of pronotum, on scutellum, underside and on femora.

Head with forehead very narrow, one-eighth as wide as rostrum, the latter transverse ( $8: 5)$, shagreened. Antennae short, only slightly longer than the width of rostrum, with proportions in length from base as $12: 9: 7: 5: 4.5: 4$ : $4: 3.8: 4: 5: 7$, ninth and tenth segments each transverse.

Pronotum 1.5 times as wide as long, the sides almost straightly narrowing
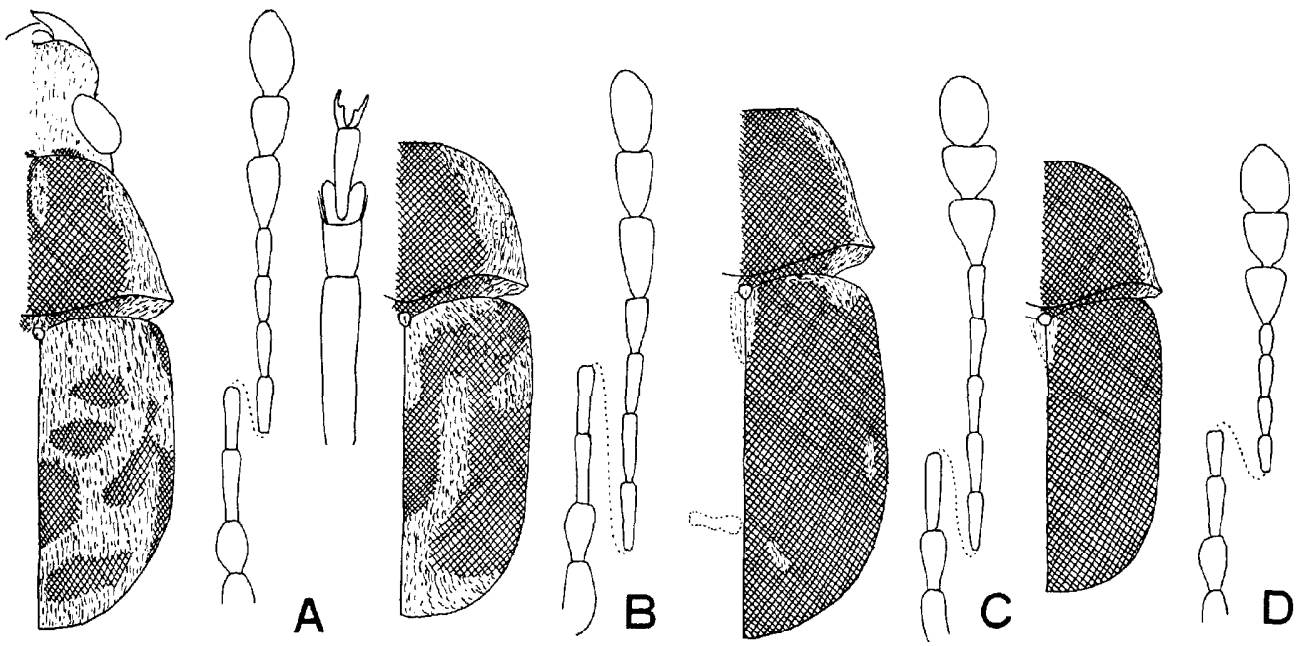

Fig. 3. Uncifer spp., holotypes, sketched at the British Museum (Natural History). A: pectoralis (Sharp), male. B: truncatus (Sharp), male. C: bruchoides (Sharp), female. D: difficilis (Sharp), female. 

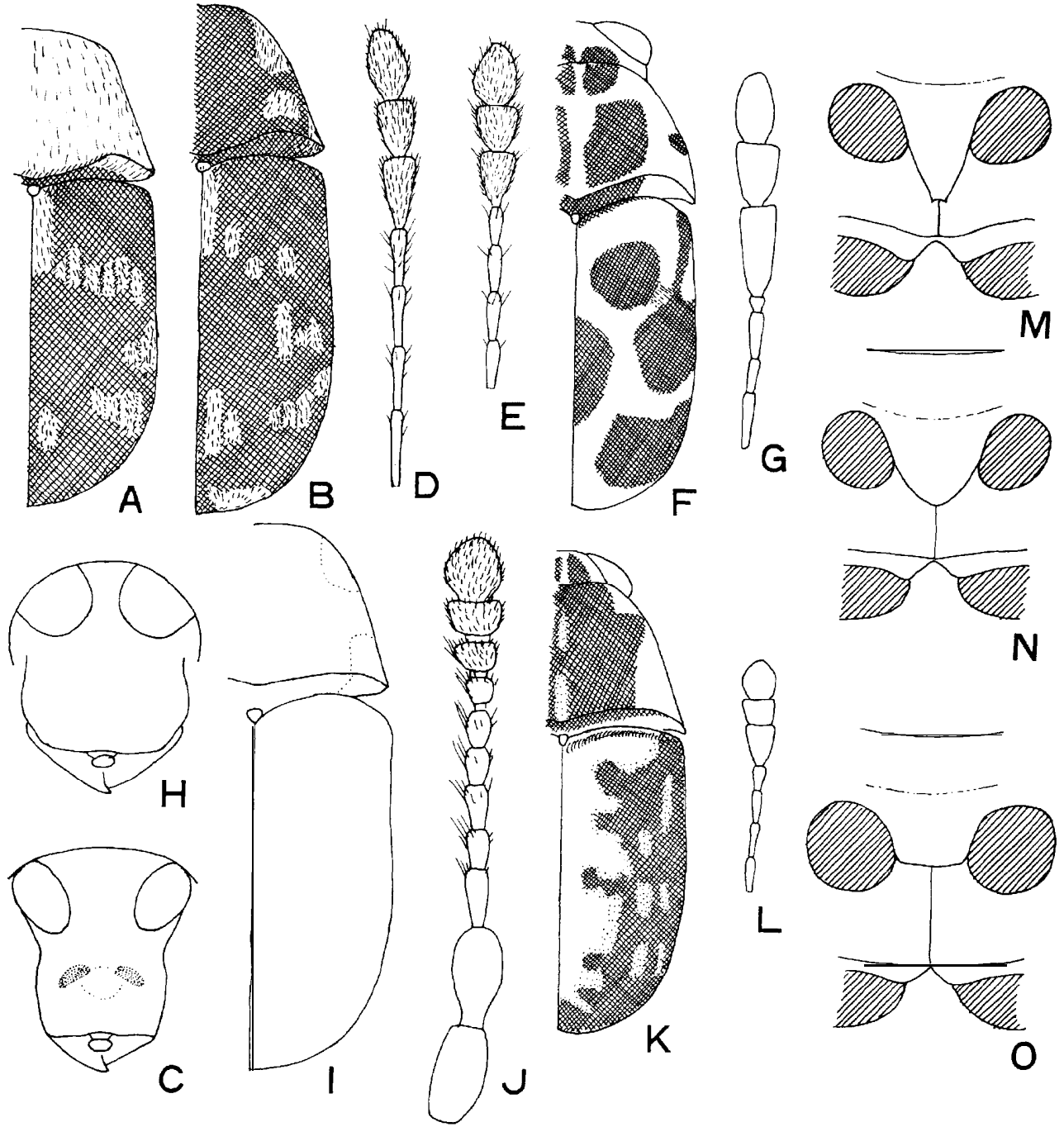

Fig. 4. Uncifer spp. A-E: bruchoides (Sharp) (A: Male. B: Female. C: Male head and rostrum. D : Male antenna. E : Ditto, female). F, G: discrepans Shibata, female. H-J: akashii sp. nov., male. K, L: sakoi Shibata, female. M, N: pectoralis (Sharp) (M: Male mesosternal process. N: Ditto, female]. 0: hispidus Shibata, male mesosternal process.

anteriorly from the widest point, dorsal carina bisinuate, parallel to the base of elytra, greyish side stripes interrupted in the middle, disk shagreened.

Scutellum triangular.

Elytra glossy, intervals slightly convex, much wider than striae, finely granulate, subbasal and subapical swellings obsolete.

Pygidium transverse $(3: 2)$, widely rounded at apex, rugose. 
Mesosternal process wide, truncate between middle coxae. Metasternum with median sulcus not reaching the anterior margin. Venter shagreened, each with a trace of small fascicle in the middle of the second and third ventrites, the former much smaller.

Legs robust, femora clavate, tibiae robust, straight, front tibiae 5.5 times as long as wide, tarsi with first segment as long as the remainings combined.

Female. Unknown.

Holotype 3 (Type No. 2298, Kyushu Univ.), Furukawa, Ibaraki Pref., 1. vi. 1969, T. Akashi leg.

Length :2.2 mm (excl. head).

Distribution : Japan (Honshu).

This small species is easily distinguished from the other species of the genus by the very narrow forehead, and compact antennae and legs.

\section{Uncifer discrepans Shibata}

(Figs. 4, F, G)

Uncifer discrepans Shibata, Ent. Rev. Japan, XXXV: 23, fig. 1, 1981 (Amami-Oshima; + ).

Specimens examined: Mt. Yonahadake, Okinawa, 1\%, 25. v. 1972, H. Irie leg.;1, 17. iv. 1974, H. Irie leg.

Distribution : Japan (Amami-Oshima and Okinawa Isls.).

\section{Uncifer bruchoides (Sharp) \\ (Figs. 3, C; 4, A-E; Photo F)}

Tropideres bruchoides Sharp, Trans. Ent. Soc. London, :316, 1891 (Kashiwagi).

Uncifer bruchoides: Morimoto, Sci. Bull. Fac. Agr. Kyushu Univ. 19: 163, 1962.

Male. Black, often the apical margin of each segment of antennae from first to eighth reddish, with whitish and dark brown pubescence, the whitish pubescence evenly covering rostrum, head, pronotum and scutellum, and also forming several patches as follows: elytra with a distinct postscutellar patch on first interval and with indistinct antemedian, mediolateral and post-median patches, patches variable in shape and numbers; underside clothed with greyish pubescence, which being longer and denser on prosternum and lateral pieces of meso- and metathorax.

Head flat transversely, punctate, forehead between eyes half as wide as rostrum. Eyes oval, maximum diameter $5 / 4$ times as long as the minimum one. Rostrum $3 / 4$ times as long as wide, with a pair of bare impressions in the middle, the median space between the impressions weakly convex. Antennae slender, with proportions in length from base as $12: 16: 19: 17: 17$ : $17: 16: 11: 17: 13: 17$, width of tenth $11(100=1 \mathrm{~mm})$. 
Pronotum transverse $(5: 3)$, the sides rather straightly narrowing anteriorly from the widest points, disk coriaceous, dorsal carina strongly bisinuate, angulate before fifth intervals of elytra, evenly concave between them, and close to scutellum in the middle, lateral carinae absent, carinulae present as a row of a few granules.

Scutellum transverse-oval.

Elytra subparallel-sided on basal two-thirds and gently rounded thence posteriorly, weakly convex anteriorly at base, transversely depressed along basal margin, intervals slightly convex, with sparse fine granules, third interval a little wider, subbasal and subapical swellings obsolete.

Pygidium as long as wide, straightly narrowing posteriorly from base to apical third, thence widely rounded at apex.

Mesosternal process truncate between middle coxae. Metasternum depressed longitudinally in the middle on posterior two-thirds. Venter rather strongly abbreviated, not depressed.

Legs with tibiae straight or very slightly incurved, tarsi with first segment as long as the remainings combined.

Female. Rostrum without bare depression. Pubescence on head, rostrum and pronotum dark brown with greyish indistinct patches as follows: head with greyish rings around eyes, pronotum with lateral wide stripes, often with narrow median stripe. Venter with fifth ventrite longer than fourth and weakly arched posteriorly.

Length : 2.4-3.6 mm (excl. head).

Specimens examined: Fuji-rindo, Mt. Fuji, Yamanashi Pref., 12 ঐ 9 ㅇ , 10-13. viii. 1976, H. Irie leg.

The holotype in the British Museum (Natural History) is a female with reduced white patches. This species is easily recognized by the bare depressions on the rostrum and greyish pubescence on the entire surface of pronoturn in male, and the black legs and body.

\section{Uncifer difficilis (Sharp)}

(Fig. 3, D; Photo G)

Tropideres difficilis Sharp, Trans. Ent. Soc. London, : 317, 1891 (Kashiwagi, Fukushima). Uncifer difficilis: Morimoto, Sci. Bull. Fac. Agr. Kyushu Univ., 19: 164, 1962.

Male. Dorsal carina of pronotum very close to elytra and almost touching to scutellum in the middle. Forehead and basal two-thirds of rostrum covered with greyish pubescence.

Female. Forehead and rostrum with brown pubescence.

S pecimens examined : Yunohana, Tateiwa-son, Fukushima Pref., $10^{\star}, 3$. vii. 1975, H. Irie leg. Oku-Nikko, Tochigi Pref., 1 구우, 1. vii. 1963, K. Morimoto leg. Marunuma, Gunma Pref., 1 q , 29. vi. 1969, T. Akashi leg. Mt. Kiyosumi, 
Chiba Pref., 1ð, 8. vi. 1963, K. Morimoto leg. Fuji-rindo, Mt. Fuji, Yamanashi Pref., $3 \circ 2 \precsim$, 10-12. viii. 1976, H. Irie leg. Makiyama, Kochi Pref., 1 ㅇ, 12. vi. 1955, K. Kojima leg. Mt. Hiko, Fukuoka Pref., 1ㅇ, 1. vi. 1975, H. Irie leg. Mt. Kumado, Fukuoka Pref., 1q, 3. viii. 1958, H. Ishibashi leg. Mt. Ariake, Tsushima, 1 우, 1. viii. 1971, H. Irie leg. Izuhara, Tsushima, 1 우, 14. vii, 1978, H. Irie leg.

Distribution : Japan (Honshu, Shikoku, Kyushu, Tsushima).

\section{Uncifer sakoi Shibata}

(Figs. 4, K, L)

Uncifer sakoi Shibata, Ent. Rev. Japan, XXXV : 24, fig. 2, 1981 (Yaku Is., female).

Specimen examined: Mt. Ariake, Tsushima, 1우 , 27. vii. 1979, T. Seno-o leg. DisTRIBUTION: Japan (Yaku and Tsushima Isls.).

\section{Uncifer hispidus Shibata}

$$
\text { (Fig. 4, 0) }
$$

Uncifer hispidus Shibata, Ent. Rev. Japan, XXXV : 26, figs. 3 \& 4, 1981 (Yaku, Amami-Oshima and Okinawa lsls.).

Specimens examined : 54 specimens from Yaku, Amami-Oshima, Nakanoshima and Okinawa Isls.

DisTRIBUTION : Japan (Yaku, Nakanoshima, Amami-Oshima and Okinawa Isls.).

\section{Uncifer truncatus (Sharp)}

(Fig. 3, B; Photo H)

Tropideres truncatus Sharp, Trans. Ent. Soc. London,: 315, 1891 (Kashiwagi, Kurigahara, Chiuzenji, Nagasaki).

Uncifer truncatus: Morimoto. Sci. Bull. Fac. Agr. Kyushu Univ., 19: 164, 1962.

Dorsal carina of pronotum distinctly angulate in the middle. Head between the narrowest point of forehead and the middle of rostrum densely covered with yellowish grey to whitish hairs in male, while in female finely with brown pubescence. Pubescent pattern of elytra considerably variable, postscutellar patch always present, in the blackish individuals elytra almost blackish except for the postscutellar patch and a few small spots, in the greyish individuals pubescence predominantly greyish, with dark brown patches as in pectoralis (fig. 3, A). Tibiae and antennae yellowish brown.

Specimens ExAmined : 54 specimens from Ibaraki Pref. (Furukawa), 
Yamanashi Pref. (Masutomi, Mt. Fuji), Nagano Pref. (Karuizawa, Matsumoto), Okayama Pref. (Kamo-cho), Fukuoka Pref. (Mt. Hiko, Mt. Kumado), Miyazaki Pref. (Mt. Shiroiwa), Kumamoto Pref. (Sendantodoro), and Kagoshima Pref. (Mt. Takachiho).

Distribution: Japan (Honshu, Shikoku, Kyushu).

\section{Key to JaPAnese SPECIES of THE genUs Uncifer JORDAN}

1 : Mesosternal process produced backwards as far as the middle of metasternum in male, or arched posteriorly a little beyond the posterior margin of metacoxa in female

Uncifer pectoralis (Sharp)

$1^{\prime}$ : Mesosternal process truncate between the middle coxae

2: Forehead between eyes $1 / 8$ times as wide as rostrum; antennae with ninth and tenth segments each transverse .......................... Uncifer akashii sp. nov.

2': Forehead between eyes at least $1 / 4$ times as wide as rostrum; tenth and ninth segments as long as or longer than wide …...................................... 3

3: Antennae with eighth segment as long as wide, dorsal carina of pronotum very strongly curved, markings distinct

Uncifer discrepans Shibata

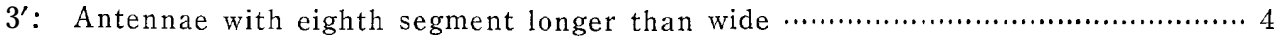

4: Legs black, elytra dark brown with white scutellum and postscutellar patch ….... 5

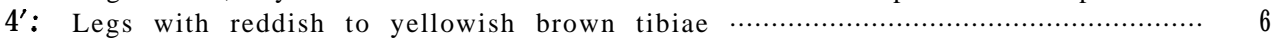

5: Male rostrum with a pair of bare depressions in the middle, elytra with several greyish patches, 2.4-3.6 $\mathrm{mm}$ in length (excl. head)

5': Male rostrum without bare depressions, elytra only with postscutellar patch, 2. 1-2. $4 \mathrm{~mm}$ in length (excl.head) ….......................... Uncife $\mathbf{r}$ difficilis (Sharp)

6: Elytra with a wide greyish stripe along suture in entire length, antennae with tenth segment a little wider than long ........................... Uncifer sakoi Shibata

6: Elytra with a common brown median patch, antennae with tenth segment longer than wide

7 : Dorsal carina of pronotum gently arched posteriorly in the median area, male rostrum with curled piles on apical two-thirds, forehead between eyes at least half as wide as rostrum in female ..................... Uncifer hispidus Shibata

7': Dorsal carina of pronotum angulate or narrowly rounded in the middle; rostrum simply pubescent; forehead between eyes less than half as wide as rostrum

Uncifer truncatus (Sharp)

Unciferina gen. nov.

TYPE-SPECIES : Unciferina japonica sp. nov.

Rostrum transverse, flat, not carinate dorsally, sharply angulate to head on the underside, with a basal transverse carina on the underside. Eyes oblong oval, dorso-lateral in position, antennal scrobes latero-ventral, invisible from above, foveiformed. Antennae reaching the base of elytra, two basal segments strongly clavate, the remaining segments longer than wide, club loosely articulated, broader than funicle, not flattened.

Pronotum transverse, widest at the lateral angles of carina, disk evenly 
convex, not carinate, not depressed, dorsal carina bisinuate and close to base, very weakly and evenly concave posteriorly in the median area, rectangularly rounded at sides, lateral carinae very short, carinulae present, short.

Elytra subcylindrical, as wide as and twice as long as pronotum, basal margin arched anteriorly and covering the part of pronotum behind carina, intervals flat or slightly convex, much wider than striae, punctate-striae regular, sixth to eighth striae not reaching the base, but ending behind humeral callus, subbasal and subapical swellings obsolete.

Front coxae narrowly separated. Mesosternal process oblique, flat, truncate between middle coxae.

Femora clavate, tibiae straight, tarsi about as long as tibiae, first segment as long as the remainings combined.

This genus is close to Uncifer Jordan and Epiplaterus Jordan, but separable from the former by the sharply angulate rostrum to head and transversely carinate base of rostrum on the underside, and from the latter by the acute hind angles of pronotum.

This genus is established for receiving the following three species from Japan. I have one more species from Taiwan.

\section{Unciferina japonica sp. nov.}

(Figs. 5, A-E)

Female. Brownish, pronotum and head darker, tibiae and antennae except for the clubs yellowish brown; pubescence brown and yellowish grey, the latter forming patches as in Fig. 5A on pronotum and elytra, head and rostrum evenly clothed with pubescence of the same colour, underside with sparse yellowish grey pubescence, which denser at side margins and on metepisterna.

Head shagreened, forehead between eyes much narrower than rostrum (5: 18); rostrum transverse ( $5: 3$ ), anterior half flat; eyes oval, maximum diameter $5 / 4$ times as long as the shortest one. Antennae with proportions in length from base as $12: 11: 11: 10: 10: 8: 9: 7: 10: 10: 12$, width of tenth 6 , club not flattened.

Pronotum transverse $(3: 2)$, the sides gently rounded and narrowed anteriorly from the widest point, disk finely shagreened, dorsal carina bisinuate, close to elytra, weakly and evenly concave posteriorly in the median area.

Scutellum small, round.

Elytra subcylindrical, parallel-sided, intervals slightly convex, finely granulate.

Pygidium as long as wide, straightly narrowing posteriorly from the base to apical third, thence rounded at apex, shagreened.

Underside shagreened. Mesosternal process flat, oblique, truncate between middle coxae. Metasternum between middle and hind coxae as long as first 
ventrite behind coxa, with a median depression on posterior half.

\section{Male, Unknown.}

Length : 2.1-2.5 mm (excl. head).

Holotype 우 (Type No. 2299, Kyushu Univ.), Mt. Tatera, Tsushima, 13. vii. 1960, H. Kamiya leg.

Paratypes:Ino, Yamadamura, Fukuoka Pref., 1 \& , 10. v. 1953, I. Hiura leg. Mt. Fukuchi, Fukuoka Pref., 1 ㅇ, 19. vi. 1969, H. Makihara leg. Mt. Inunaki, Fukuoka Pref., 1q, 10. vii. 1960, J. Nagao leg.

Distribution: Japan (Kyushu, Tsushima).

\section{Wnciferina brevifrons sp. nov.}

(Figs. 5, F-H)

Very close to japonica sp. nov., but separable from it by the following
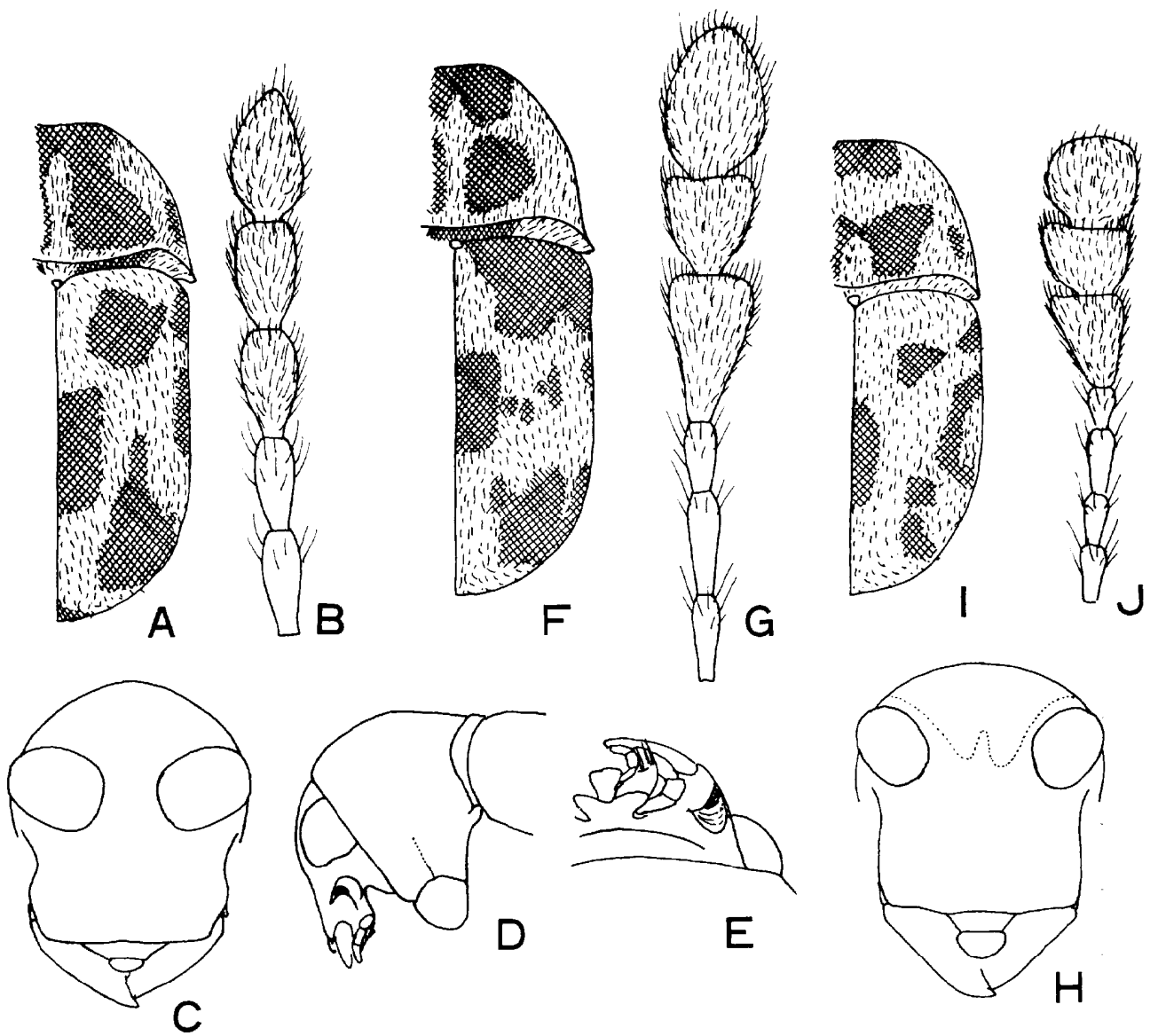

Fig. 5. Unciferina spp. A-E: japonica sp. nov., female. (E: Ventral aspect of head showing transverse carina). F-H: brevifrons sp. nov., female. I, J: persimilis sp. nov., female. 
points.

Greyish pubescence on head denser around eyes and forming a median short stripe between eyes, and also covering sparsely on the basal half of rostrum. Basal brown patches of elytra reaching the base. Antennae with proportions in length from base as $11: 11: 13: 11: 9: 8: 9: 7: 13: 10: 13$, width of tenth 8 . Forehead between eyes half as wide as rostrum.

Male. Unknown.

Length : $2.3 \mathrm{~mm}$ (excl. head).

Holotype 우 (Type No. 2300, Kyushu Univ.), Kashiwa City, Chiba Pref., 31. v. 1969, T. Akashi leg.

Distribution : Japan (Honshu).

\section{Unciferina persimilis sp. nov.}

(Figs. 5, I, J)

Very close to above described species, but separable from them by the characters as follows.

Head excepting vertex and rostrum with greyish pubescence, forehead between eyes $1 / 4$ times as wide as rostrum, the latter twice as wide as long. Antennae with proportions in length from base as $11: 10: 8: 6: 5: 4.5: 6: 4:$ 8:6:8, width of tenth 8 , ninth segment triangular, tenth segment transverse, terminal segment rounded. Dorsal carina of pronotum weakly angulate in the middle, lateral carinae long reaching apical $1 / 4$.

Male. Unknown.

Holotype 우 (Type No. 2301, Kyushu Univ.), Nishinakama, Amami-Oshima, 3-5. viii, 1969, H. Makihara leg.

Paratypes: Same data as holotype, 1 우.Izumi, Okinawa, 1우, 21. x. 1968, H. Hirashima leg.

Distribution: Japan (Amami-Oshima and Okinawa Isls.).

KEY TO SPECIES OF THE GENUS Unciferina GEN. NOV.

1 : Lateral carinae of pronotum reaching anteriorly to $1 / 4$ from apex; antennae with tenth segment transverse, ultimate segment rounded; forehead between eyes $1 / 4$ times as wide as rostrum ........................ Unciferina persimilis sp. nov.

1': Lateral carinae of pronotum very short; antennae with tenth segment lon-

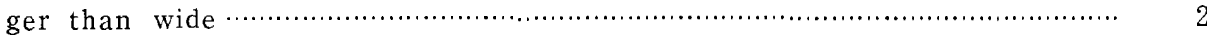

2: Forehead between eyes half as wide as rostrum; antennae with tenth seg-

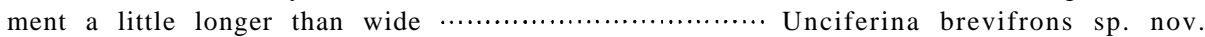

$2^{\prime}$ : Forehead between eyes $5 / 18$ the width of rostrum; antennae with tenth seg-

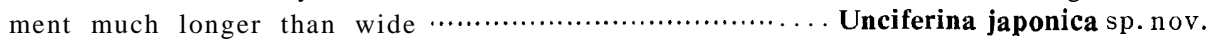




\section{Rhaphitropis Reitter}

Tropideres subgenus Rhaphitropis Reitter, Faun. Germ., V: 5, 1916.

Rhaphitropis: Jordan, Ann. Mag. Nat. Hist., (9)XVI : 257, 1925; Morimoto, Bull. Gov. Forest Exp. Sta., (246) : 44, fig. 86, 1972. (Type-species: Tropideres marchicus Herbst, designated by Jordan, 1925).

The species now assigned to this genus are somewhat heterogeneous and can be divided into three groups as follows:

The marchicus-group: Elytra regularly punctate-striate, basal margin arched anteriorly and covering the basal part of pronotum; antennae not very slender; dorsal carina of pronotum run parallel to the base of elytra ; mesosternal process simple.

The guttifera-group: Elytra regularly punctate-striate, basal margin truncate; antennae slender; dorsal carina of pronotum not parallel to the base of elytra; mesosternal process simple.

The midori-group: Elytra irregularly punctate-striate on dorsal surface ; mesosternal process deeply depressed at basal half and apical area vertical, latero-apical corners bent posteriorly and sharply prolonged into long processes.

The marchicus-group is similar to Uncifer Jordan, and contains discus Jordan, tamilis Jordan, truncatoides sp. nov., niger sp. nov., and imperfectus Sharp. The midori-group is conspicuous and enough to deserve as an independent genus, but my material is scanty at present.

\section{Rhaphitropis japonicus Shibata}

(Figs. 6, I, J)

Rhaphitropis japonicus Shibata, Ent. Rev. Japan, XXXI: 95, 1978 (Nara, Kyoto).

Specimens examined : Misakubo, Shizuoka Pref., 1 ㅇ, 16. vii. 1954, K. Kojima leg. Mt. Tebako, Kochi Pref., 1 q, 7. viii. 1957, K. Morimoto leg. Mt. Inunaki, Fukuoka Pref., 1우 10. vi. 1960, J. Nagao leg. Mt. Homan, Fukuoka Pref .,1午, 5. vi. 1971, H. Irie leg. Mt. Kumado, Fukuoka Pref., 1, 15. vi. 1958, H. Ishibashi leg. Tatsudayama, Kumamoto City, 1§, 2. vi. 1977, K. Morimoto leg. Shiratani, Yaku Is., $1 \precsim$, 9. v. 1972, H. Irie leg.

Distribution: Japan (Honshu, Shikoku, Kyushu, Yaku Is.).

\section{Rhaphitropis guttifer (Sharp)}

(Figs. 6, M-P; Photos J, K)

Tropideres guttifer Sharp, Trans. Ent. Soc. London, : 314, 1891 (Nagasaki) ; Johraku, Shin Konchu, V(10): 33, 1952 (Larva, pupa, adult, ill.).

Rhaphitropis guttifer: Morimoto, Sci. Bull. Fac. Agr. Kyushu Univ., 19 : 163, 1962; Nakane, 
Icon. Ins. Jap. col. nat. ed., II: 351, pl. 176, fig. 9, 1963.

Tropideres concolor Sharp, Trans. Ent. Soc. London,: 314, 1891 (Yokohama; 3)

Rhaphitropis concolor: Morimoto, Sci. Bull. Fac. Agr. Kyushu Univ., 19: 163, 1962.-syn. nov.

Specimens examined : Nokendo side, Kanazawabunko, Kanagawa Pref., $3 \precsim 2$ 우, 1. x. 1980, S. Miyakawa leg. Oku-Nikko, Tochigi Pref., 1 §`, 15. vii. 1963, T. Akashi leg. Midoro-ike, near Kyoto, $1 \precsim$, 21. vi. 1918, M. Suzuki leg. Mt. Tachibana, Fukuoka Pref., $1 \precsim 1$, vi. 1972, S. Ogata leg. Mt. Joyama, Munakata, Fukuoka Pref .,1 $\varsigma^{\nwarrow}$,23. v. 1972, K. Kido leg. Mt. Inunaki, Fukuoka Pref., $1 \precsim 1$ 우, 10. vi. 1960, J. Nagao leg. Mt. Homan, Fukuoka Pref., 1우, 9. v. 1971,
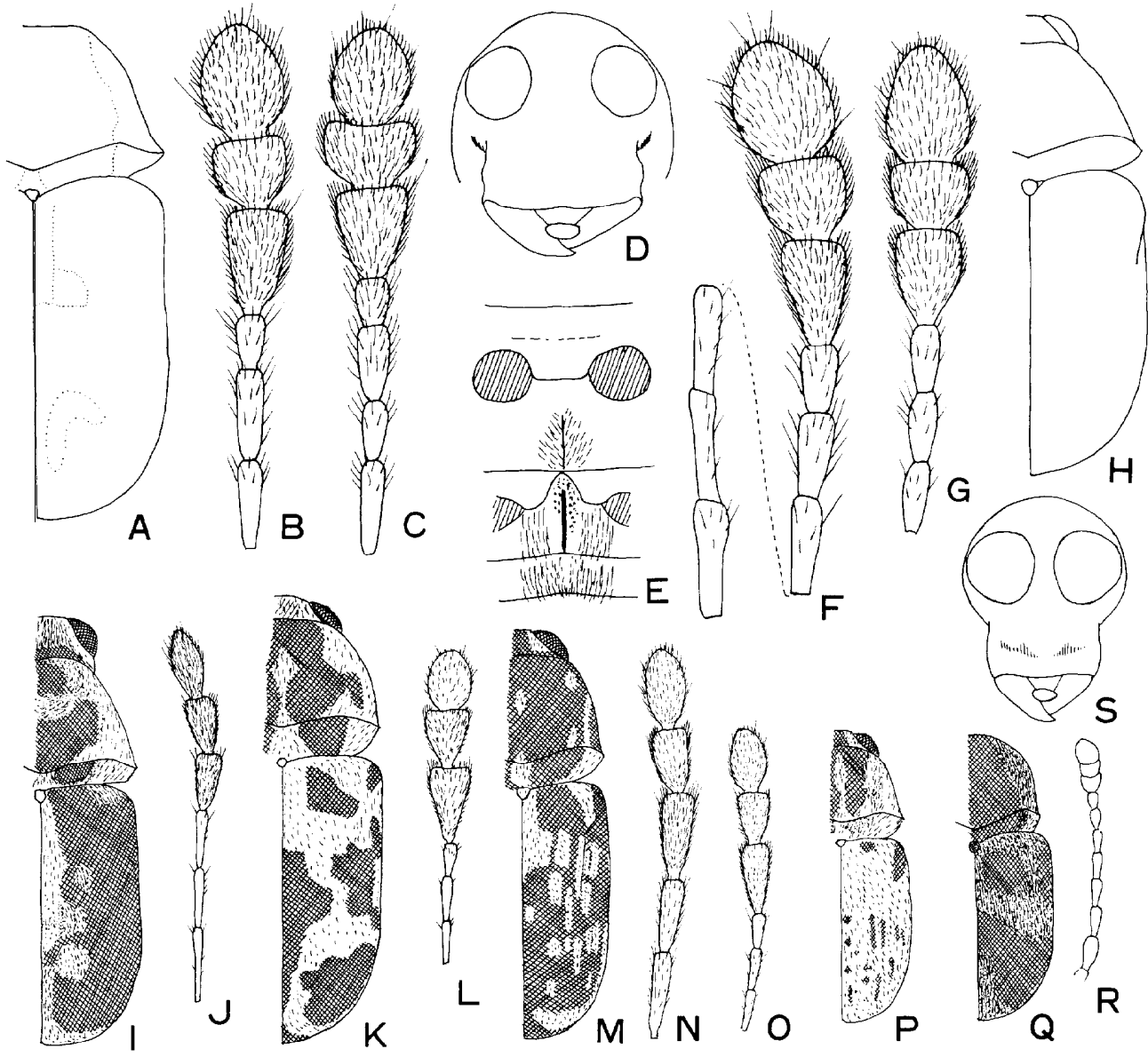

Fig. 6. Rhaphitropis spp. A-C: truncatoides sp. nov. (B : Male antenna, C: Ditto, female). D-H: niger sp. nov. (D: Male head and rostrum, E: Metasternum and two basal ventrites of male, F: Male antenna, G: Ditto, female). I, J: japonicus Shibata, male. K, L: nigromaculatus sp. nov., male. M-P: guttifer (Sharp) (N: Male antenna. 0: Ditto, female. P: small greyish form =concolor). Q-S: imperfectus (Sharp), holotype, sketched at the British Museum (Natural History). 
H. Irie leg. Tatsudayama, Kumamoto City, $3 \gtrsim 4$, 15. iv. 1970, K. Morimoto leg, ; $1 \overbrace{}^{\star}, 24$. iv. 1977, K. Morimoto leg.; 1 \&, 20. v. 1977, K. Morimoto leg. Izuhara, Tsushima, 1 § 1 우 17. v. 1971, H. Irie leg.

Distribution : Japan (Honshu, Kyushu, Tsushima) .

One male collected at Nokendo side, Kanagawa Pref. agrees well with the description of concolor, and the other four specimens taken at the same time show the wide range of variation from guttifer-type to concolor one. This species is variable in scaly pattern, and concolor may be a small and greyish individual of guttifer. The antenna1 proportions used by Sharp for separating condor from guttifer is nothing but the sexual character of the same species.

\section{Rhaphitropis nigromaculatus sp. nov.}

(Figs. 6, K, L)

Male. Brownish black to black, anterior margin of rostrum and femora dark reddish brown, tibiae and antennae yellowish brown; derm clothed with greyish and dark brown pubescence, the latter forming following patches as in Fig. 6, K: the basal patches on elytra often obsolete on fourth intervals, median lateral patches often reduced in size to form small three spots, or combined with sutural patch and forming conjoint band.

Head densely punctate, vertex bare, forehead and ocular margins with greyish pubescence ; forehead between eyes $3 / 7$ times as wide as rostrum; the latter transverse $(3: 5)$, similarly pubescent as on forehead on basal half and sparser thence anteriorly, transversely flattened on apical third. Antennae reaching the middle of elytra, with proportions in length from base as $10: 12$ : $12: 11: 10: 9.5: 10: 6: 17: 12: 14$, width_of tenth 10 .

Prothorax transverse (5:6), the sides evenly rounded and narrowing anteriorly from the widest point, transverse carina bisinuate, straightly convergent internally and shortly rounded in the middle, narrowly rounded at sides, lateral carinae very short, carinulae present, complete, disk densely punctulate or finely rugose.

Scutellum small, round.

Elytra cylindrical, parallel-sided, basal margin almost straight, finely marginate, subbasal and subapical swellings obsolete, regularly punctate-striate, intervals flat and much wider than striae.

Pygidium as long as wide, straightly narrowing apically to the apical third and widely rounded at apex, clothed with greyish pubescence.

Underside clothed with greyish pubescence, a little denser at side margins of thorax, mesosternal process simply truncate between middle coxae. Venter with a distinct median sulcus, inside of the sulcus bare and coriaceous, each ventrite slightly contracted.

Legs with femora clavate, tibiae straight, simple. tarsi slender, first 
segment as long as the remainings combined.

Female. Antennae with first segment of club a little shorter, with proportions in length from seventh as $10: 7: 15: 12: 13$. Forehead between eyes about half as wide as rostrum. Venter not sulcate, fifth ventrite much wider than fourth in the middle, with arched apical margin.

Length : 2.1-2.5 mm (excl. head).

Holotype o (Type No. 2302, Kyushu Univ.), Shirahama, Iriomote Is., 5. iv. 1974, H. Irie leg.

Paratypes: Same data as holotype, 1․ Same locality as holotype, 2 ㄱ, 3. v. 1974, H. Irie leg. Mt. Bannadake, Ishigaki Is., 1ð, 30. viii. 1969, H. Makihara leg. ; 1 ㅇ, 25. v. 1974, H. Irie leg. Nishinakama, Amami-Oshima, 1 우, 3. viii. 1969, H. Makihara leg.

Distribution : Japan (Amami-Oshima, Ishigaki and Iriomote Isls.).

This new species is easily recognized by the scaly pattern on elytra and the longitudinally sulcate abdomen in entire length in male.

\section{Rhaphitropis truncatoides sp. nov.}

(Figs. 6, A-C)

Male. Black to dark brown, femora and mouth parts reddish brown, tibiae reddish to yellowish brown, each segment of antennae from base to eighth dark reddish brown with paler apex; derm clothed with dark brown and greyish pubescence, the latter covering sparsely on forehead and rostrum, lateral margins and an antescutellar patch behind carina of pronotum, postscutellar vague patch on elytra and on the underside, the greyish pubescence being so sparse that the dorsal surface dark brownish at first sight.

Head finely shagreened, forehead between eyes $2 / 5$ times as wide as rostrum; eyes oval, maximum diameter $6 / 5$ the length of the shortest; rostrum transverse $(5: 3)$, flat on anterior half. Antennae reaching the base of pronotum, with proportions in length from base as $12: 10: 14: 10: 10: 7: 8: 6$ : $11: 8: 12$, width of tenth 9 .

Pronotum transverse (10:7), the sides almost straightly narrowed to the middle, thence slightly rounded anteriorly, disk shagreened as on vertex, dorsal carina bisinuate, rather distant from the base of elytra, angulate in the middle, lateral carinae very short, carinulae entire.

Scutellum transverse, densely covered with greyish pubescence.

Elytra parallel-sided on basal two- thirds, intervals flat, finely granulate, subbasal swellings very weak, subapical swellings obsolete.

Pygidium slightly wider than long, straightly narrowing apically to the middle, thence rounded at apex, finely shagreened.

Mesosternal process truncate between middle coxae. Metasternum with median sulcus entire. Venter not depressed, weakly abbreviated, fifth ventrite 
a little longer than fourth in the middle.

Female. Antennae with eighth segment much shorter than seventh (2:3), clubs less elongate.

Length : 2. 5-2.8 mm (excl. head).

Holotype (Type No. 2303, Kyushu Univ.), Nanatsutaki, Kodomari-son, Aomori Pref., 6. viii. 1976, H. Irie leg.

Paratypes: Same data as holotype, 3 . Hirakubo, Hinoemata-son, Fukushima Pref., $2 \precsim$, 8-9. viii. 1976, H. Irie leg. Sapporo, Hokkaido, 1 우, 13. viii. 1968, K. Kushigemachi leg.

Distribution : Japan (Hokkaido, Honshu).

This new species is similar to Uncifer truncatus (Sharp) in appearance, but the dorsal carina of pronotum is more distant from elytra.

Rhaphitropis imperfectus (Sharp), comb. nov.

(Figs. 6, Q-S; Photo I)

Tropideres imperfectus Sharp, Trans. Ent. Soc. London, : 316, 1891 (Kashiwagi).

Uncifer imperfectus: Morimoto, Sci. Bull. Fac. Agr. Kyushu Univ., 19: 164, 1962.

Specimens examined: Mt. Ariake, Tsushima, 1 ㅇ, 13. vii. 1978, H. Irie leg.

Distribution: Japan (Honshu, Tsushima).

This species is easily recognized by the very narrow forehead and compact clubs of antennae.

\section{Rhaphitropis niger sp. nov.}

(Figs. 6, D-H)

Male. Black, with dark brown pubescence above, scutellum covered with sparse greyish brown pubescence, elytra often with indistinct greyish brown short patch behind scutellum, underside with sparse greyish to brownish grey pubescence.

Head densely with fine punctures, forehead between eyes one-third as wide as rostrum, gently convex; rostrum transverse (10:7), thinly clothed with greyish brown to brownish grey pubescence. Antennae reaching the base of elytra, with proportions in length from base as $10: 12: 12: 10: 9: 7$ : $7: 6: 10: 8: 14$, width of tenth 9 .

Pronotum transverse $(3: 2)$, the sides slightly curved and rapidly converging anteriorly from the widest point, dorsal carina fairly distant from elytra, distinctly angulate in the middle, lateral carinae very short, carinulae present, disk shagreened, "dark brown pubescence a little denser at sides, greyish brown pubescence forming an indistinct patch on each side behind carina.

Scutellum round.

Elytra a little longer than wide (13:10), parallel-sided, intervals weakly 
convex, much wider than striae, weakly depressed at base between humeri and scutellum, basal and subapical swellings obsolete.

Pygidium as long as wide, straightly narrowing posteriorly from base to apical third, then widely rounded at apex, finely granulate.

Mesosternal process truncate at apex between middle coxae, flat, oblique, granulate. Metasternum depressed in the middle on posterior two-thirds, glossy median carina not reaching apex. Venter shagreened, slightly abbreviated, first ventrite narrowly depressed in the middle and with a median carina, the depression extending posteriorly to second ventrite to form narrow sulcus.

Legs with femora clavate, tibiae straight, tarsi with first segment as long as the remainings combined.

Female, Forehead between eyes $2 / 5$ times as wide as rostrum. Antennae with eighth segment much shorter than seventh $(4: 5)$. Venter neither sulcate nor carinate, fifth ventrite much longer than fourth, arched posteriorly.

Length :2.2.-3.1 mm (excl. head).

Holotype o (Type No. 2304, Kyushu Univ.), Mt. Shiroiwa, Miyazaki Pref., 25. vii. 1974, H. Irie leg.

Paratypes: Hirakubo, Hinoemata-son, Fukushima Pref., 1 우, 9. viii. 1954, H. Irie leg. Misakubo, Shizuoka Pref., 1우, 17. viii. 1954, K. Kojima leg. Fujirindo, Mt. Fuji, Yamanashi Pref., 1 $\delta^{\wedge}$ 10. viii. 1976, H. Irie leg. Same data as holotype, $2 \preccurlyeq 7$ 우. Shiiya-toge, Miyazaki Pref., 1우, 27. vii. 1973, Y. Ota leg. ; $1 ð$, 13. vi. 1976, H. Irie leg. Nishinoiwa, Izumi-mura, Kumamoto Pref., 1 우, 2. vii. 1972, Y. Ota leg. Sendantodoro, Izumi-mura, Kumamoto Pref., 1우, 25. v. 1972, Y. Ota leg.

Distribution: Japan (Honshu, Kyushu).

This new species is closest to imperfectus (Sharp), but the forehead between eyes is much wider and the antennae clubs are a little longer as noted in the key.

\section{Rhaphitropis iriei sp. nov.}

(Figs. 7, A-D)

Male. Brownish black, mouth parts reddish brown, legs yellowish, antennae yellowish at three basal segments, thence darkened apically, club dark brown. Head with a yellow hair tuft, which covering the full width of forehead just above the narrowest point between eyes; rostrum densely covered with white hairs except for the orange yellow anterior margin. Pronotum with greyish hairs on anterior third and with three greyish indistinct patches behind the carina, the remaining area covered sparsely with dark brown pubescence. Scutellum covered with greyish hairs. Elytra evenly clothed with greyish hairs leaving five dark brown indistinct patches, the median patch 

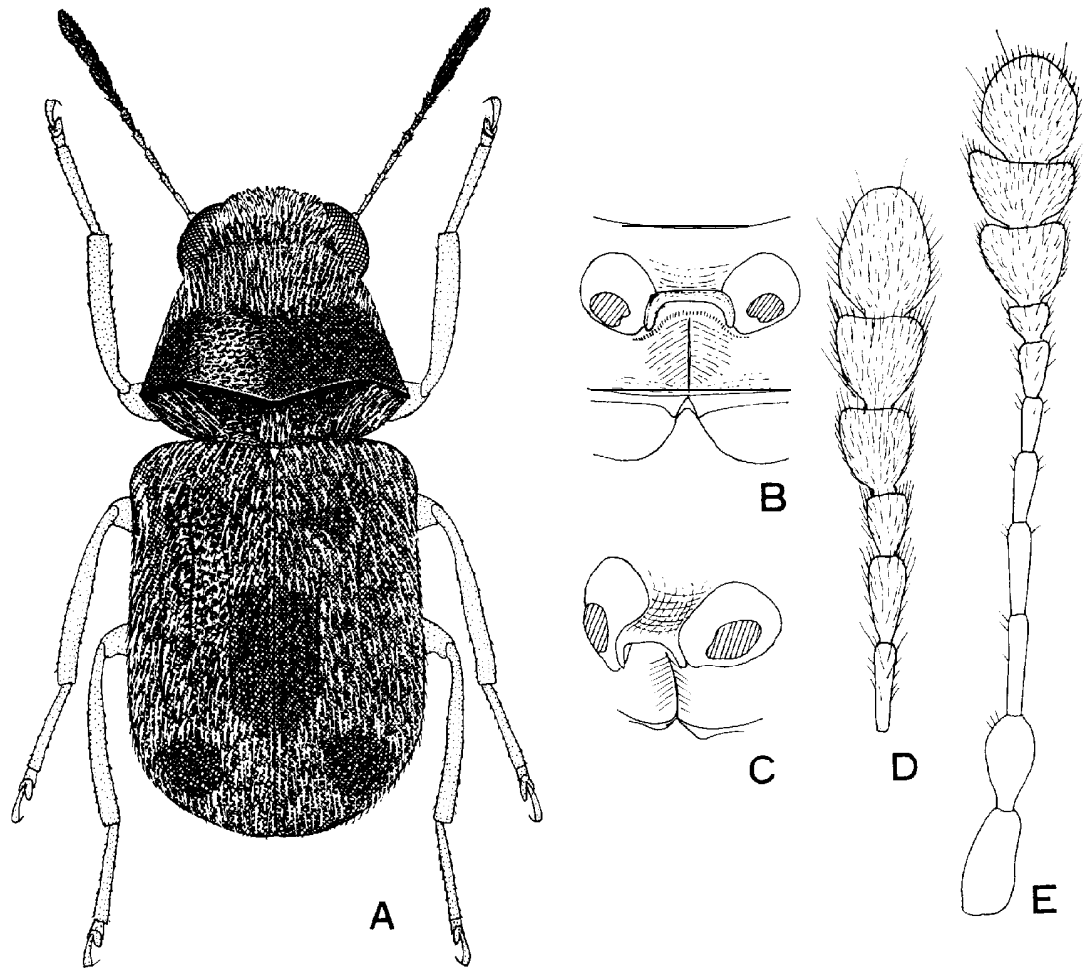

Fig. 7. A-D: Rhaphitropis iriei sp. nov., male. (B, C: Mesosternal process). E: Rhaphitropis flavipes sp. nov., male antenna.

along the median part of suture larger, longer than wide, a pair of subbasal patches smaller and obscure, and a pair of subapical patches round and almost reaching the latero-posterior margin of elytra. Lateral margins of thorax and abdomen widely covered with greyish hairs.

Head punctate, forehead between eyes less than half as wide as rostrum (5:11) ; rostrum twice as wide as long, widest above antenna1 sockets. Antennae with proportions in length from base as $12: 9: 10: 9: 10: 8: 8: 6: 9$ : 9: 13, width of tenth 9 , seventh and eighth segments clavate.

Pronotum transverse $(7: 5)$, hexagonal, the sides straightly narrowing anteriorly from the widest point, transverse carina bisinuate, angulate posteriorly in the middle, disk finely rugose, lateral carinae absent, carinulae present.

Scutellum small, triangular.

Elytra subquadrate, almost straight at base, very slightly widening posteriorly from humeri to apical third and evenly rounded towards apex, subbasal swellings indistinct, subapical swellings obsolete, third, fifth and seventh intervals slightly costate and glossy in the median part, first to fourth striae and first, second and fourth intervals confusedly punctate and granulate. 
Pygidium as long as wide, straightly narrowing anteriorly from the base, then rounded at apex, coarsely punctate.

Underside finely shagreened. Mesosternal process peculiar in shape, deeply depressed at anterior basal area, the posterior part almost vertical,yellowish brown, glossy, and the lateroapical corners bent posteriorly and sharply prolonged into long processes. Metasternum deeply depressed in the middle, with a median sulcus. Venter with first to third ventrites flattened in the middle, first to fourth, especially fourth, ventrites contracted, weakly costate in the median part of posterior margin on second to fourth ventrites.

Legs with femora clavate; tibiae with anterior pairs straight, posterior two pairs slightly curved internally, tarsi slender, first segment much longer than the remainings combined $(5: 4)$.

Female. Unknown.

Length : $2.0 \mathrm{~mm}$ (excl. head).

Holotype ð̊ (Type No. 2305, Kyushu Univ.), Hirano, Yaku Is., 12. vii. 1973, H. Irie leg.

Distribution : Japan (Yaku Is.).

This new species is close to midori Shibata in having the similar shape of pronotum, elytra and tarsi, and also with characteristic hair-tuft on head, but easily separable from the latter by the characters noted in the key.

\section{Rhaphitropis flavipes sp. nov.}

(Fig. 7, E)

Male. Brownish black, mouth parts and legs yellowish, antennae yellowish at two basal segments, thence darkened apically, club brownish black, elytra dark brown. Head with pale brownish grey hairs around eyes, rostrum with greyish hairs which denser between antenna1 insertions and sparser at anterior margin, where the hairs becoming yellowish; pronotum sparsely with greyish hairs at sides, antescutellar patch indistinct; scutellum and elytra evenly and sparsely clothed with greyish hairs; lateral surfaces of thorax and abdomen sparsely clothed with greyish hairs.

Head finely rugose, forehead between eyes one-third as wide as rostrum, the latter transverse $(10: 7)$. Antennae with proportions in length from base as $11: 9: 10: 9: 7: 5.5: 6: 5: 8: 7: 11$, width of tenth 11 , eighth segment much shorter than seventh, as long as wide, tenth segment transverse.

Pronotum as in iriei, dorsal carina evenly concave.

Elytra rather flat, punctate-striae irregular on dorsal surface and confusedly rugose with intervals, subbasal and subapical swellings obsolete.

Pygidium as in iriei. Mesosternal process as in iriei, the terminal margin serrate. Venter not flattened in the middle. Legs as in iriei.

Female. Unknown. 
Length : $1.7 \mathrm{~mm}$ (excl. head).

Holotype $\precsim$ (Type No. 2306, Kyushu Univ.), Kampira Fall, Iriomote Is., 15. iv. 1975, H. Irie leg.

Distribution: Japan (Iriomote Is.).

This new species is very close to iriei sp. nov., but the hair tuft on head is absent, the eighth segment of antennae is much shorter than the seventh, the hairy patter of pronotum is different, and the terminal margin of mesosternal process is serrate,

\section{Rhaphitropis midori Shibata}

Rhaphitropis midori Shibata, Ent. Rev. Japan, XXXI: 93, 1978 (Nara ; đ).

Distribution: Japan (Nara).

This species remains unknown to me.

Key to Japanese Species (males) of the genus Rhaphitropis Reitter

1 : Elytra regularly punctate-striate, tarsi with first segment as long as the remainings combined, body more or less convex, mesosternal process oblique, flat, normally truncate

$1^{\prime}$ : Elytra irregularly punctate-striate and confusedly rugose with intervals on dorsal surface, tarsi with first segment much longer than the remainings combined, body rather flat, mesosternal process vertical, latero-posterior corners sharply pointed posteriorly

2 : Antennal clubs slender, each segment much longer than wide, ninth segment about as long as eighth, elytra blackish with greyish patches ….............. 3

$2^{\prime}$ : Antennal clubs with ninth segment much longer than eighth, tenth seg-

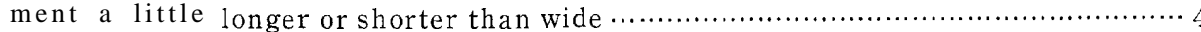

3: Middle femora each with a glossy carina in the middle along outer ventral side; elytra with an irregular median longitudinal stripe along suture in entire length ................................................. Rhaphitropis japonicus Shibata

3': Middle femora expanded internally, but not carinate; elytra with a short post-scutellar greyish patch along suture together with many small spots in

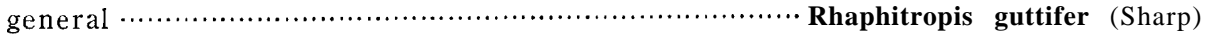

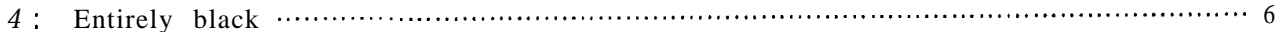

$4^{\prime}$ : Legs with reddish to yellowish brown tibiae, dorsal carina of pronotum

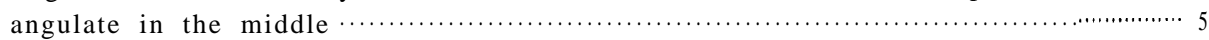

5 : Venter with a longitudinal median sulcus in entire length, elytra greyish with blackish patches, 2.1-2.5 $\mathrm{mm}$ in length (excl. head)

Rhaphitropis nigromaculatus sp. nov.

5': Venter not depressed, elytra dark brown with vague greyish patches, 2.5-2.8 $\mathrm{mm}$ in length ( $\mathrm{excl}$. head) ......................... Rhaphitropis truncatoides sp. nov.

$6:$ Forehead between eyes $1 / 6-1 / 7$ times as wide as rostrum . . . . . . . . . . ........ Rhaphitropis imperfectus (Sharp)

$6^{\prime}$ : Forehead between eyes $1 / 3$ times as wide as rostrum $\cdots .$. Rhaphitropis niger sp. nov.

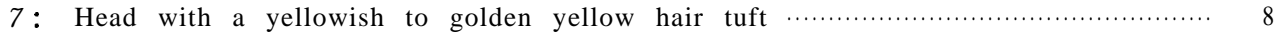

7': Head without hair tuft; pronotum greyish at sides; antennae with eighth segment as long as wide, tenth segment transverse $\cdots .$. . Rhaphitropis flavipes sp. nov. 
8: Pronotum with greyish hairs on apical third Rhaphitropis iriei sp. nov.

8I: Pronotum with a sulfur yellow pubescence for major dorsal area, the colour gradated into greyish white laterally or basally

Rhaphitropis midori Shibata

\section{Exechesops Schoenherr}

Exechesops Schoenherr, Vetensk. Akad. Forh., : 54, 1846 (Type-species : Exechesops quadrituberculatus Schoenherr, by original designation).

Zygaenodes Pascoe, Ann. Mag. Nat. Hist., (3) IV: 328, 1859 (Type-species: Zygaenodes wollastoni Pascoe, by monotypy).

\section{Exechesops leucopis (Jordan)}

(Photo L)

Zygaenodes Eeucopis Jordan, Nov. Zool., XXXVI: 91, 1928 (Tonkin); Tokunaga, Kansai Konchu Zasshi, 4: 81, 1937; Miwa, Mushi, 10: 158, 1937; Tokunaga, Bull. Takarazuka Insectary, (12) : 1, 1941 ; Hirayama, Nat. Col. I1l. Col. Jap., : 82, pl. 28, fig. 28, 1940; Tokunaga, Shin Konchu, II: 268, 1949; Nakane, Icon. Ins. Jap., : 125, fig. 3617, 1950; Nakane, Icon Ins. Jap. col. nat. ed., II: 350, pl. 175, fig. 26, 1963.

Exechesops Eeucopis: Wolfrum, Col. Cat. Suppl., 102, Anthribidae: 22, 1953.

Specimens examined : 33 examples from Fukuoka Pref. (Mt. Hiko, Mt. Fukuchi), Kyoto City, Tsushima (Izuhara, Mt. Tatera, Mt. Ohoshi), and Kumamoto City. Most of them emerged from seeds of Styraxiaponica and obassia.

Distribution: Japan (Honshu, Kyushu, Tsushima), Korea, China, Tonkin.

\section{Tribe CORRHECERINI}

Corrhécérides Lacordaire, Gen. Col., VII: 547, 1866 plus Tropidérides vrais, 1. c. : 529.

Nessiarini Morimoto, Bull. Gov. Forest Exp. Sta., (246) : 38, 1972.

\section{Gibber Jordan}

Gibber Jordan, Stett. Ent. Zeit., LVI: 176, 1895 (Type-species: Gibber tuberculatus Jordan, by original designation).

This genus is similar to Dissoleucas Jordan and Directarius Jordan in the shape of prothorax, but easily separable from them by the oblong-oval eyes, of which the lower edges much closer to each other than the upper.

Gibber brevirostris (Sharp) is close to callistus Jordan, and nodulosus (Sharp) is to tuberculatus Jordan and frenatus Jordan.

Gibber brevirostris (Sharp), comb. nov.

(Photos P, Q)

Tropideres brevirostris Sharp, Trans. Ent. Soc. London, : 307, 1891 (Sapporo). 
Dissoleucas brevirostris:Wolfrum, Col. Cat. Suppl., 102, Anthribidae : 27, 1953; Nakane, Icon. Ins. Jap. col. nat. ed., II: 351, pl. 176, fig. 7, 1963.

Specimens examined: Yunohana, Fukushima Pref., 1우 25. vii. 1970, T. Akashi leg. Daibosatsu- toge, Yamanashi Pref., 5 §3우, 26-30. vi. 1975, H. Irie leg, Mt. Hotakayama, Gunma Pref., 1ð, 15. vii. 1975, H. Irie leg. Mt. Tebako, Kochi Pref., $1 \delta^{7} 4$ 우, 7-10. viii. 1957, K. Morimoto leg. Mt. Homan, Fukuoka Pref., 1 우, 10. vi. 1930, T. Esaki leg. Mt. Hiko, Fukuoka Pref., $1 \precsim 1$ 우, 19. v. 1939, H. Hori leg. Mt. Kumado, Fukuoka Pref., 1우, 3. viii. 1958, H. Ishibashi leg. Shiiya, Kumamoto Pref., $2 \precsim 1$ ㅇ, 27. vii. 1973, Y. Ota leg.

Distribution : Japan (Hokkaido, Honshu, Shikoku, Kyushu) .

Gibber incisus (Sharp), comb. nov. (Photo M)

Tropideres incisus Sharp, Trans. Ent. Soc. London, : 308, 1891 (Ichiuchi, Oyama).

Directarius incisus: Jordan, Nov. Zool., XIX: 142, 1912 (Formosa: Taihorisho) ; Nakane, Icon. Ins. Jap. col. nat. ed., II: 351, pl. 176, fig. 6, 1963.

SPecimens examined : Ohnabe-rindo, Kawazu-cho, Shizuoka Pref., $1 \delta^{\rtimes}$ 우, 13. v. 1980, J. Okuma leg. Misakubo, Shizuoka Pref., 1 우, 16. vii. 1954, K. Kojima leg. Fukakurakyo, Fukuoka Pref., $2 \precsim 1$ 우, 15. ix. 1971, H. Irie leg.

Distribution : Japan (Honshu, Kyushu), Taiwan.

Gibber nodulosus (Sharp), comb. nov.

(Photos N, 0)

Tropideres nodulosus Sharp, Trans. Ent. Soc. London, : 308, 1891 (Japan).

Dissoleucas nodulosus: Wolfrum, Col. Cat. Suppl., 202, Anthribidae : 27, 1953: Nakane, Icon. Ins. Jap. col. nat. ed., II : 351, pl. 176, fig. 8, 1963.

S Pecimens EXAmined : Nukabira, Hokkaido, 1, 21. vii. 1959, K. Morimoto leg. Yunomata, Shimokita, Aomori Pref., 1우, 13. vii. 1956, K. Morimoto leg. Marunuma, Gunma Pref., 1ㅇ, 29. vi. 1969, T. Akashi leg. Masutomi, Yamanashi Pref., 1ð, 23. vii. 1956, H. Kamiya leg. Koganesawa, Yamanashi Pref., 1 ð, 14. ix. 1975, S. Miyakawa leg. Daibosatsu-toge, Yamanashi Pref., 1 ð 1 ㅇ, 27. vi. 1975, H. Irie leg. Koike, Fukui Pref., 1ðð, 20-24. vii. 1964, H. Sasaji leg. Izuhara, Tsushima, 1§, 16. v. 1971, H. Irie leg. Mt. Ariake, Tsushima, 1 우, 14. v. 1971, H. Irie leg.

Distribution: Japan (Hokkaido, Honshu, Kyushu, Tsushima), Siberia (Wladiwostock).

\section{Gibber ogasawarensis sp. nov.}

(Fig. 8; Photos R, S)

Male. Brownish black to black with brownish tinge, antennae, apices of 

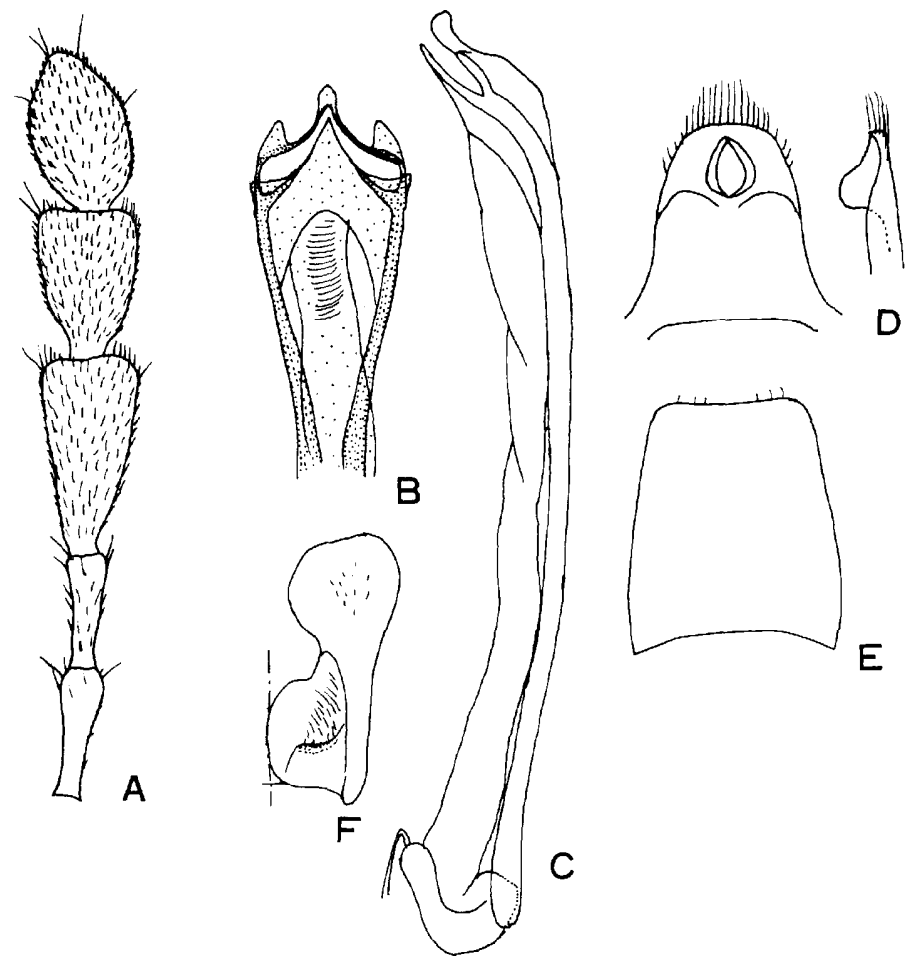

Fig. 8. Gibber ogasawarensis sp. nov., male. A : Antenna. B : Apex of penis, ventral aspect. C : Penis, lateral aspect. D : Cap-piece of tegmen, ventral and lateral aspects. E: Tergite of genital segment. F : Ditto, sternite, right half.

femora, tibiae and tarsi reddish brown, variegated with greyish, brownish and blackish hairy patches. Head with a semicircular indistinct greyish patch on vertex, brownish grey indistinct patches above eyes, and with a fine median greyish line between eyes; rostrum densely covered with greyish hairs ; pronoturn with a median greyish line, which interrupted by tubercle, with a transverse short greyish band on each side at apical fifth, similar but less distinct bands just before the carina, and with a pair of lateral vague greyish patches behind the carina; scutellum covered with greyish hairs; elytra with several small black spots on first, seventh and ninth intervals, with a large black spot each at the middle of third and fifth intervals and with some small spots on declivity of third and fifth intervals, black spot on the basal tubercle of third interval variable in size, but always larger, greyish lines present between black spots on third, fifth and seventh intervals, and also with a pair of transverse greyish bands on subapical swellings, apical area behind declivity of elytra and pygidium brownish grey ; underside covered with greyish hairs with brownish tinge, the hairs greyish and denser on the underside of pronotum, 
lateral pieces of meso- and metathorax, and lateral margins of abdomen, venter with two pairs of brown patches on each ventrites, smaller one at anterolateral corners and the other larger one semiround in shape at a little interior from the sides.

Head punctate, forehead between eyes one-third as wide as rostrum, slightly depressed; rostrum twice as wide as long, transversely and weakly depressed between antenna1 insertions. Antennae reaching the base of elytra, with proportions in length from base as $8: 7: 10: 9: 7: 6.5: 6.5: 6: 11: 7.5:$ 8.5, width of tenth 5.2, with a few short setae at apex of each segment, second segment clavate.

Pronotum transverse (40:27), the sides straightly narrowing anteriorly and posteriorly from the widest point, median tubercle indistinct, transverse carina curved posteriorly on each side and rounded to very short lateral carinae, carinulae present.

Scutellum transverse.

Elytra longer than wide $(11: 8)$, subquadrate, almost straight at base, basal hump very large, median tubercle on third interval weak, subapical tubercle on fifth interval at declivity obsolete, weakly depressed behind the subapical greyish band.

Pygidium slightly longer than wide, weakly narrowing posteriorly from base and rounded to the truncate apex, slightly convex, without median carina.

Venter convex transversely and concave longitudinally.

Femora strongly clavate, each with a large glossy blackish ventral patch. Tibiae each with an antebasal brown and a postmedian blackish rings. Tarsi blackish on the basal half of first segment, middle tarsi with a batch of short setae at the ventral margin of apex of first segment.

Aedeagus: penis with three points at apex, median point thick and weakly warped ; cap-piece of tegmen with a cup-like structure ; tergite of genital segment truncate at apex, sternite formed of a pair of sclerites with round apex.

Female. Rostrum and forehead with a reverse Y-shaped greyish patch. Venter almost straight longitudinally in the middle. First segment of middle tarsi simple.

Length : 2.8-4.0 mm (excl. head).

Holotype $\sigma^{\top}$ (Type No. 2307, Kyushu Univ.), Kuwanokiyama, Hahajima, 2. vii. 1976, H. Irie leg.

Paratypes: Same locality as holotype, 2 우, 23. vi. 1976, H. Irie leg. ; 1 하우, 29. vi. 1976, H. Irie leg. ; $4 \gtrsim 4$ ㅇ, 2-3. vii. 1976, H. Irie leg. Komoridani, Hahajima, $2 \precsim 3$ 우, 30. vi \& 3. vii. 1976, H. Irie leg. Okimura, Hahajima, 2 우, 4. vi. 1975, T. Seino leg. Nananodaira, Hahajima, 1ð, 4. vii. 1976, H. Irie leg. Hahajima, $1 \precsim$, 25. viii. 1971; 1 ð 1 ㅇ, 17. ix. 1971; 1 , 13. ix. 1979, K. Kojima leg. (reared from the dead trunk of Leucaena leucocephala). Mikazukiyama, Chichijima, 
1 우, 1. vi. 1973, H. Fujita leg.; $2 \jmath^{\Uparrow} 1$ 우, 30. v. 1975, T. Seino leg. Kitafu. kurosawa, Chichijima, $1 \succsim, 20$. vi. 1976, H. Irie leg. Yoakeyama, Chichijima, 1ठ, 20. vi. 1976, Y. Kurosawa leg. Chuosan, Chichijima, 1,11. vi. 1973, H. Fujita leg. ; 2 ㅇ, 20. vi. 1975, T. Seino leg.

Distribution : Japan (Ogasawara Isls.).

Key to JAPANeSE SPECIES OF the Genus Gibber JORDAN

1: Elytra each with a tubercle on the declivity of fifth interval and two tuber-

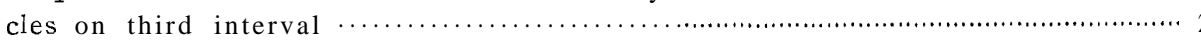

1: Elytra with two tubercles on third intervals, fifth interval not tuberculate; antennae with eighth segment longer than wide and a little shorter than

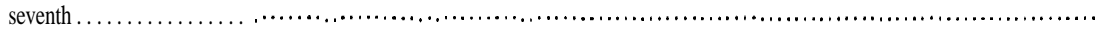

2: Elytra with an additional tubercle on the declivity of seventh and ninth intervals respectively; pronotum reddish brown, with a pair of oblique greyish fasciae at anterolateral corners and with three greyish patches behind the carina; elytra blackish in general, with reddish brown apex and basal areas between humeri and basal humps, variegated with black and brownish hairs on first intervals; antennae with eighth segment as long as wide and much shorter than seventh....................................... Gibber incisus (Sharp)

$2 \because$ Elytra not tuberculate on seventh and ninth intervals; pronotum and elytra black, variegated with greyish, brownish and blackish hairs, greyish hairs forming a median line, which interrupted by tubercle, and a pair of oblique fasciae at antero-lateral corners ; elytra with several blackish spots on the alternate intervals ; antennae with eighth segment longer than wide and as long as seventh Gibber nodulosus (Sharp)

3: Elytra paler, brown or greenish brown to greenish; basal humps of elytra weaker; forehead between eyes half as wide as rostrum in both sexes; venter less depressed in male …........................... Gibber brevirostris (Sharp)

$3^{\prime}$ : Elytra and pronotum blackish brown to brownish black, without greenish tinge; forehead between eyes one-third as wide as rostrum in male, a little narrower than half the width of rostrum in female; basal humps of elytra conspicuous; venter concave longitudinally in male

Gibber ogasawarensis sp. nov.

\section{Phaulimia Pascoe}

Phaulimia Pascoe, Ann. Mag. Nat. Hist., (3)IV: 437, 1859 (Type-species : Phaulimia ephippiata Pascoe, by monotypy) ; Lacordaire, Gen. Col., VII: 551, 1866; Morimoto, Bull. Gov. Forest Exp. Sta., (246) : 36, 45, 1972 (Phaulimia= Hypseus).

Hypseus Pascoe, Ann. Mag. Nat. Hist., (3)V: 39, 1860 (Type-species: Hypseus fascicularis Pascoe, by monotypy) ; Lacordaire, Gen. Col., VII: 539, 1866.

\section{Phaulimia incerta (Shibata)}

(Fig. 9, E; Photo Y)

Hypseus incertus Shibata, Ent. Rev. Japan, XVI: 2, pl. 1, fig. 2, 1963 (Amami-Oshima; 우). Phaulimia incerta: Shibata, Ent. Rev. Japan, XXXIV: 43, 1980 (Ishigaki, Taiwan).

Male. Forehead between eyes $1 / 3$ times as wide as rostrum, the latter 

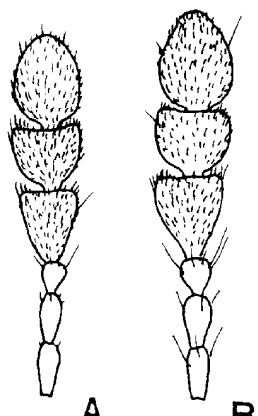

B

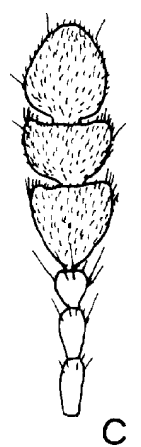

C

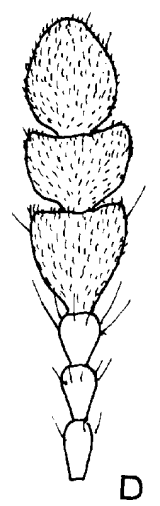

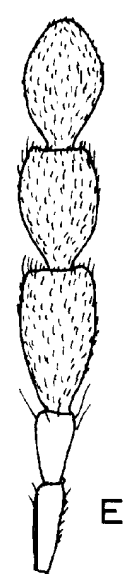

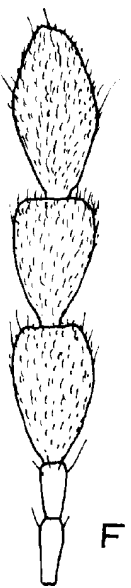

Fig. 9. Phaulimia spp., antenna. A :annulipes sp. noy,., male. B aberrans (Sharp), male. C: rufobasis sp. nov., male. D : confinis (Sharp), male. E : incerta (Shibata), male. F : decorata (Shibata), female.

transverse (5:3). Antennae with loose clubs, eighth segment twice as long as wide, ninth segment 1.5 times as long as wide, tenth segment a little shorter than ninth and as long as eleventh. Elytra with four tubercles on third interval, basal and median tubercles very large, the others small, fifth interval with a small tubercle, seventh interval with three or four indistinct small tubercles. Metepisternum with a large median oblong blackish brown patch surrounded by luteous hairs. Claws dentate in both sexes.

Length : 3.9-5.8 mm (excl. head).

Specimens examined: Mt. Yonahadake, Okinawa, 1o, 21. v. 1976, T. Ogasawara leg. Mt. Omotodake, Ishigaki, 1ㅇ, 7. v. 1974, H. Irie leg.

Distribution: Japan (Amami-Oshima, Okinawa and Ishigaki Isls.), Taiwan.

\section{Phaulimia decorata (Shibata)}

(Fig. 9, F; Photo X)

Hypseus decoratus Shibata, Ent. Rev. Japan, XVI: 1, pl. 1, fig. 1, 1963 (Amami-Oshima). Phaulimia decorata: Shibata, Ent. Rev. Japan, XXXIV: 26, 1980.

Specimen examined: Shinmura, Amami-Oshima, 1\%, 26. iv-5. v. 1967, H. Takizawa leg.

Distribution : Japan (Amami-Oshima Is.).

\section{Phaulimia angusta sp. nov.}

(Figs. 10, E, F; Photo c)

Male. Dark reddish brown, slightly rufescent on two basal segments of antennae, basal part of elytra and tibiae, variegated with blackish, brownish, 
ash-grey and white pubescence, white pubescence larger and forming following patches : a small median spot on forehead, a short median stripe on vertex, a median stripe on pronotum, which interrupted widely in the middle and at apex, a pair of small lateral spots on pronotum a little before the middle, a pair of small spots on pronotum behind carina, small spot before and an oblong spot behind the median black spot on third interval of elytra; ash-grey pubescence scattered on rostrum and on vertex, and forming several indistinct patches on pronotum, elytra tessellated with indistinct vague brownish and ash-grey spots on alternate intervals, median dark brown or blackish oblong spot on third interval conspicuous.

Pygidium and underside with ash-grey pubescence, which being denser on anterior and posterior parts of metepisterna. Legs with ash-grey pubescence, with brownish basal, median and terminal rings on tibiae.

Head strongly punctate, not depressed, forehead between eyes half as wide as rostrum, the latter transverse (20:11), weakly depressed in the middle; eyes 1.5 times as long as wide. Antennae short, not reaching the base of pronotum, with proportions in length from base as $10: 10: 7: 6: 6: 4.5$ : $4.5: 4: 10: 8: 12$, width of eighth 5 , tenth 10 , club rather compact.

Pronotum transverse (5:4), the sides gently rounded from the middle to apex, slightly sinuate before the angles of carina, disk sparsely and irregularly punctate, interstices between punctures finely rugose, dorsal carina slightly
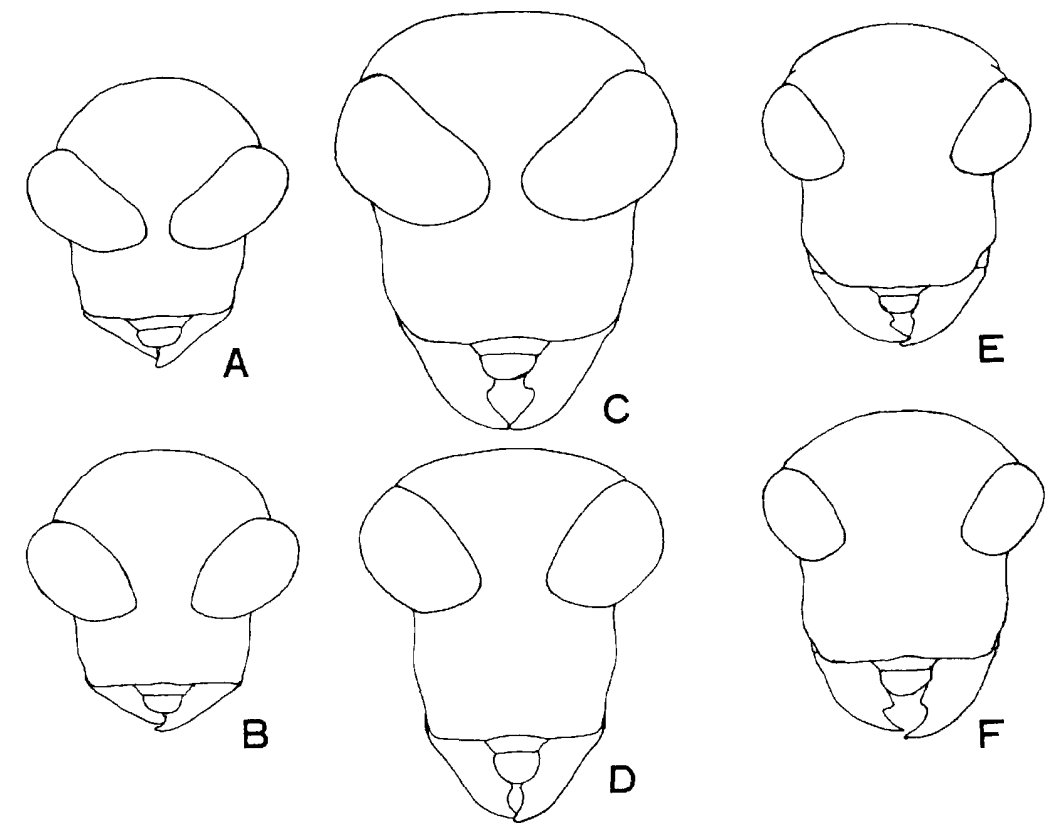

Fig. 10. Phaulimia spp., head and rostrum. A, C, E: Male. B, D, F: Female. A, B: annulipes sp. nov. C, D: minor Shibata. E, F : angusta sp. nov. 
convex and widely rounded at sides, lateral carinae reaching anteriorly a little beyond the middle, longitudinal carinulae entire.

Scutellum minute, with white pubescence.

Elytra slender, about 1.6 times as long as wide, parallel-sided on basal three-fourths, basal margin weakly convex, subbasal swellings slight.

Pygidium directing antero-ventrally, strongly punctate, as long as wide, rounded at apex.

Pro-, meso- and metasterna sparsely with strong punctures excepting smooth mesosternal process and median part of metasternum. Venter punctulate at sides. Claws of hind legs dentate, but smaller than those on median ones.

Female. Forehead between eyes slightly wider, 4/7 times as wide as rostrum. Pygidium vertical.

Length : 2.5-3.4 mm (excl. head).

Holotype ðð (Type No. 2308, Kyushu Univ.), Mt. Omotodake, Ishigaki, 30. iii. 1973, H. Irie leg.

Paratypes: Same locality as holotype, 1ð, 21. v. 1974, H. Irie leg. ; $1 \delta^{\dagger}, 9$. iv. 1975, H. Irie leg.; 1 § 2 우, 11. iv. 1975, H. Irie leg.; 1 우, 16. iv. 1975, H. Irie leg.; 1 ㅇ, 19. iv. 1975, H. Irie leg. Yoshihara, Ishigaki, 1ㅇ, 27. iv. 1974, H. Irie leg.; 1 ㅇ, 17. v. 1974, H. Irie leg. Mt. Bannadake, Ishigaki, 1 ð 2 우, 3. v. 1969, H. Makihara leg.;1우, 25. v. 1974, H. Irie leg.;1ð, 24. vi. 1977, H. Irie leg. Funaura, Iriomote, $1 \precsim 1$ ㅇ, 3. v. 1974, H. Irie leg. Mt. Yonahadake, Okinawa, $1 \delta^{\natural}$, 8. vi. $1977, \mathrm{H}$. Irie leg.

Distribution : Japan (Okinawa, Ishigaki and Iriomote Isls.).

This new species is close to brachystomus (Jordan) in general shape and markings, but the forehead is wider and the claws of hind legs are dentate and symmetrical in male.

\section{Phaulimia minor Shibata}

(Figs. 10, C, D; Photo a)

Phaulimia minor Shibata, Ent. Rev. Japan, XXXIV: 43, fig. 5, 1980 (Ogasawara: Chichijima ; 우).

Male. Forehead between eyes $1 / 6$ the width of rostrum, the latter twice as wide as long. Antennae with compact clubs, eighth segment 1.5 times as long as wide, tenth segment a little wider than long. Metepisternum with a large median oblong blackish patch surrounded by ash-grey hairs. Venter depressed in an oval shape on four basal segments. Claws of hind legs unarmed.

SPectmens examined: Okimura, Hahajima, 2우 4. vi. 1975, T. Seino leg. Komoridani, Hahajima, 1ત, 7. vi. 1973, H. Fujita leg. 
Distribution: Japan (Ogasawara Isls : Chichijima, Hahajima).

Three specimens before me are larger, 2.9, 3.4, $3.9 \mathrm{~mm}$ in length (excl. head), while $2.4 \mathrm{~mm}$ in the type.

\section{Phaulimia annulipes sp. nov.}

(Figs. 9, A ; 10, A, B; Photo b)

Male. Prosternum, meso- and metathorax and abdomen blackish brown to black, dorsal surface reddish brown with black spots. Head with dark brown spots which continued transversely at hind margin, the other area between eyes and rostrum reddish brown with dense white hairs; pronotum reddish brown on the anterior half, predominantly blackish on the posterior half with following reddish brown patches : median longitudinal patch behind the middle, a pair of small lateral spots behind carina, median ( )-shape spots and a pair of short stripes running posteriorly from the angles of the last mentioned spots, reddish brown patches with greyish pubescence and blackish area with blackish pubescence. Elytra reddish brown with blackish fascicles and spots, first intervals with a fascicle before the middle, tessellated with indistinct greyish brown and brown spots from the middle to apex, second interval with a subbasal black spot, third, fifth, seventh and ninth intervals with blackish spots, the basal spots arranged obliquely backwards from the subbasal spot of second interval to the middle of lateral margin, median fascicle of third interval large and conspicuous, small spots on fifth and seventh intervals arranged transversely in the middle, small fascicles arranged transversely on declivity and near apex, shoulder with black patch, third interval just behind the median black fascicle with white conspicuous white fascicle. Antennae dark brown with pale two basal segments. Legs pale reddish brown, hind femora each with a broad median blackish ring, tibiae each with a broad median and short terminal rings, often infuscate at the base, these rings with dark brown pubescence.

Head weakly depressed, forehead between eyes $1 / 8$ times as wide as rostrum, the latter strongly transverse $(17: 6.5)$, almost flat, with a trace of median carina; eyes almost twice as long as wide. Antennae reaching the base of pronotum, with proportions in length from base as $14: 14: 11: 10: 10: 8$ : $7: 6: 14: 10: 16$, width of eighth 5 , tenth 11 , club rather compact.

Pronotum transverse (15:11), widest at base, slightly sinuate just before the angles of carina, disk densely punctate, dorsal carina almost straight in the middle and slightly curved backwards at sides, sharply angulate to the lateral carinae, which reaching anteriorly a little beyond the middle, longitudinal carinulae sharp and entire.

Scutellum minute, with sparse greyish hairs.

Elytra rather strongly convex at base, transversely depressed between 
humeri, subbasal swellings weak, median area around fascicles of first and third intervals evenly and slightly convex.

Prosternum before coxae, mesosternum excepting process and lateral part of metasternum strongly punctate, mesosternal process and median area of metasternum with dense fine ash-grey pubescence, mesosternal process finely punctate, metasternum with a deep post-coxal sulcus, which being shallower to the sides, median area flat, unpunctate. Venter very sparsely punctate. Claws of hind legs simple.

Female. Forehead between eyes a little wider, 3/10 the width of rostrum. Claws normally dentate.

Length : 2.5-2.9 $\mathrm{mm}$ (excl. head).

Holotype ॐ (Type No. 2309, Kyushu Univ.), Okimura, Hahajima, 4. vi. 1974, T. Seino leg.

Paratypes: Mt. Chuo, Hahajima, 1ठ1웅. 20. vi. 1975, T. Seino leg.

Distribution: Japan (Ogasawara Isls.: Hahajima).

This new species is similar to minor Shibata and brunneus Jordan in the marking of pronotum, but the black and white fascicles in the middle of third interval are characteristic. This is also similar to fascicularis Pascoe and vestitus Jordan in the marking of elytra, but these species have distinct greyish patches on pronotum.

\section{Phaulimia confinis (Sharp), comb. nov.}

(Fig. 9, D; Photos T, U)

Tropideres confinis Sharp, Trans. Ent. Soc. London,: 309, 1891 (Hitoyoshi).

Ulorhinus confinis: Jordan, Nov. Zool., XXXIV: 121, 1928; Nakane, Icon. Ins. Jap. col. nat. ed., II : 352, pl. 176, fig. 26, 1963.

Ulorhinus germanus Jordan, Nov. Zool., XXXIV: 89, 1928 (Tonkin) .-syn. nov.

S pecimens examined: Mt. Hiko, Fukuoka Pref., 19, 10. vi. 1937, H. Hori leg. Mt. Fukuchi, Fukuoka Pref., 1우, 27. vii. 1970, H. Makihara leg. Mt. Ariake, Tsushima, 1 우, 22. v. 1961, H. Irie leg. ;1 우 14. v. 1971, H. Irie leg. Mt. Tatera, Tsushima, 1ð1우 18-20. v. 1961, H. Kamiya leg. Sendantodoro, Kumamoto Pref., 1ð, 25. ix. 1972, Y. Ota leg. Hetsuka-Kawaguchi-Magome, Sata, Kagoshima Pref., $1 \precsim 1$ ㅇ, 26. v. 1952, Esaki \& Hirashima leg.

Distribution: Japan (Honshu, Shikoku, Kyushu), Tonkin.

The claws of hind legs are not dentate in the male.

Phaulimia aberrans (Sharp), comb. nov.

(Fig. 9, B; Photos V, W)

Tropideres aberrans Sharp, Trans. Ent. Soc. London, : 309, 1891 (Japan).

Ulorhinus aberrans: Jordan, Nov. Zool., XXXIV: 121, 1928; Iga, Col. Ill. Ins. Jap., Col. : 138, 
pl. 49, fig. 18, 1955; Nakane, Icon. Ins. Jap. col. nat. ed., II : 352, pl. 176, fig. 25, 1963 ; Iga, Col. 111. Ins. Jap., Col., enlarged \& rev. ed.: 196, pl. 61, fig. 1355, 1977.

Specimens examined: Mt. Manzaburo-dake, Izu, Shizuoka Pref., 1오 19. v. 1980, J. Okuma leg. Miyatsuka, Niijima Is., 2 우, 15. v. 1979, H. Fujita leg. Ishijirogawa, Shikinejima Is., 1 우, 7. v. 1979, J. Okuma leg. Koike, Fukui Pref., 1 우 1우, 20-24. vii. 1964, H. Sasaji leg. Mt. Kawanori, Tokyo, 1 우, 28. v. 1968, H. Takizawa leg. Mt. Hiko, Fukuoka Pref., 1 우, 30. vii. 1972, S. Ogata leg. Mt. Homan, Fukuoka Pref., 3 $\vec{o}$, 5. vi. 1971, H. Irie leg. Mt. Kumado, Fukuoka Pref., 1우, 1. viii. 1957, Y. Miyake leg. ; 1 , 5. viii. 1957, H. Ishibashi leg. Okinoshima Is., Chikuzen, $1 \partial^{\star}$, 26. vii. 1962, H. Hayashi \& M. Shiga leg. Mt. Ookue, Miyazaki Pref., 2ð, 23. v. 1969, H. Makihara leg. Tokara-Nakanoshima Is., 1 우, 1. vii. 1973, H. Irie leg.

Distribution: Japan (Honshu, Shikoku, Kyushu, Okinoshima Is., Nakanoshima Is.).

The claws of hind legs are not dentate in the male.

\section{Phaulimia rufobasis sp. nov.}

(Fig. 9, C; Photo Z)

Male. Blackish brown to reddish brown. Head blackish brown to reddish brown, with luteous grey pubescent spots, three between the hind margin of eyes and one on forehead; rostrum reddish brown with luteous grey pubescence; pronotum blackish brown with reddish brown spots, luteous grey pubescence forming a median stripe, which widely interrupted at apex and in the middle, ash-grey pubescence forming indistinct patches; elytra dark brown with reddish bases, dorso-posterior area between fourth intervals behind median tubercles slightly rufescent, alternate intervals tessellated with blackish brown and ash-grey spots, the latter more or less luteous on reddish areas, black spot on subbasal swelling of second and often fourth intervals distinct, median black fascicle on the tubercle of third interval oblong-oval, conspicuous, third, fifth and seventh intervals with small black spots on weak tubercles, subapical black spot on third interval indistinct; underside with greyish pubescence, metepisterna greyish on anterior and posterior corners ; femora greyish with wide brownish ring, tibiae with dark brown pubescence on apical two-thirds, with a greyish subbasal ring and visibly reddish at base.

Head slightly depressed, densely punctate, forehead between eyes $1 / 6-1 / 7$ times as wide as rostrum, the latter twice as wide as long, with a short median carina; eyes twice as long as wide. Antennae with proportions in length from base as $15: 15: 14: 11: 11: 9: 8: 7: 15: 11: 17$, width of eighth 7 , tenth 14, club rather compact.

Pronotum transverse (15:11), the sides sinuate before the angles of 
carina, disk strongly punctate, the interstices about as wide as the diameter, dorsal carina weakly convex with small notch in the middle, and very narrowly rounded or almost angulate at sides, lateral carinae reaching anteriorly a little beyond the middle, longitudinal carinulae entire.

Scutellum small, rounded, similarly pubescent as nearby elytra.

Elytra 1.5 times as long as wide, parallel-sided on basal three-fourths, strongly arched at base, subbasal swellings moderate, as high as the median tubercles on third interval.

Pygidium slightly wider than long, rounded at apex, strongly punctate.

Pro-, meso- and metathorax on the underside strongly punctate excepting smooth median area of metasternum. Venter punctulate at sides. Claws of hind legs not dentate.

Female. Forehead between eyes $1 / 3$ times as wide as rostrum. All claws similarly dentate.

Length :2.6-4. $1 \mathrm{~mm}$ (excl. head).

Holotype o (Type No. 2310, Kyushu Univ.), Kozuka, Mt. Daigatake, Hakone, Kanagawa Pref., 18. vi. 1978, S. Miyakawa leg.

Paratypes: Same data as holotype, 2 우. Mt. Manzaburodake, Izu, Shizuoka Pref., 1 우, 19. v. 1980, J. Okuma leg. Mt. Kumado, Fukuoka Pref., 1우, 3. viii. 1959, Y. Miyake leg. Shiiya-toge, Miyazaki Pref., 1 ․, 8.v. 1975, S. Ogata leg. Mt. Shiroiwa, Miyazaki Pref., $1 \gtrsim, 25$. vii. 1974, H. Irie leg.

Distribution: Japan (Honshu, Kyushu).

This new species is closest to aberrans (Sharp), but can be separable from it by the characters noted in the key.

Key to Japanese species of the genus Phaulimia Pascoe

1: Antennae slender, eighth segment at least twice as long as wide, clubs loosely articulated, each segment longer than wide, elytra with distinct tubercles ….... 2

$\mathbf{1}^{\prime}$ : Antennae shorter, eighth segment at most 1.5 times as long as wide, tenth

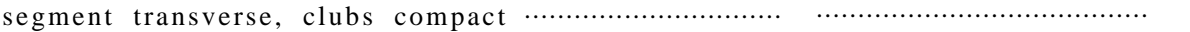

2: Elytra with two large tubercles on third interval, the other tubercles much smaller; metepisternum with an oblong-oval blackish median patch surrounded by luteous hairs....................................... Phaulimia incerta (Shibata)

2': Elytra with three tubercles of the moderate size on third interval; metepisternum with an oblong-oval brownish patch surrounded by ash-grey pubescence ................................................................. Phaulimia decorata (Shibata)

3: Apical part of elytra and pygidium densely covered with luteous grey to greyish pubescence......................................... Phaulimia confinis (Sharp)

3'. Apical part of elytra pubescent as on the other part of elytra …................... 4

4: Forehead between eyes half as wide as rostrum in male, claws of hind legs dentate in male; body slenderer, elytra 1. 6 times as long as wide, metepisternum whitish with brownish spot on posterior half; body length 2.5-3.4 $\mathrm{mm}$ (excl. head) ........................................ Phaulimia angusta sp. nov.

$4^{\prime}$ : Forehead between eyes $1 / 6-1 / 8$ the width of rostrum and claws of hind legs 
unarmed in male; body robuster, elytra at most 1.5 times as long as wide, metepisternum almost dark brown with whitish anterior and posterior mar-

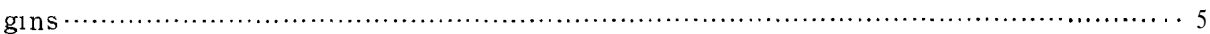

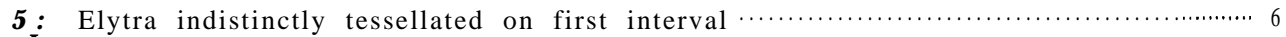

5!: Elytra with a blackish fascicle on first interval a little before the middle, just behind the median black fascicle on third interval with a white conspicuous fascicle Phaulimia annulipes sp. nov.

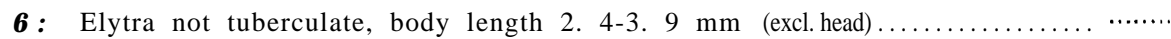

6': Elytra tuberculate on third interval, length $3.3-4.7 \mathrm{~mm}$ (excl. head) …............ 7

7 : Elytra concolorous dark brown, with four weak tubercles on third interval, basal tubercle on subbasal swelling indistinct and with small black spots, second to fourth tubercles with fasciculate black pubescence, the fourth one near apex small, but conspicuous as the third; tibiae usually with median

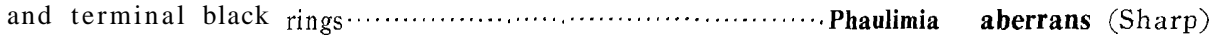

7': Elytra dark brown with reddish bases and dorso-posterior area between fourth intervals behind median tubercles slightly rufescent, third interval with three weak tubercles, the third one behind the middle inconspicuous, with small black fascicle, subapical black spot small, not fasciculate; tibiae with dark brown pubescence on apical two-thirds …....... Phaulimia rufobasis sp. nov.

\section{Oxyderes Jordan}

Oxyderes Jordan, Nov. Zool., XXXIV : 114, 1928 (Type-species : Hypseus frenatus Jordan, by original designation) ; Morimoto, Bull. Gov. Forest Exp. Sta., (246) : 45, 1972.

\section{Oxyderes fastigata (Jordan) \\ (Photo d)}

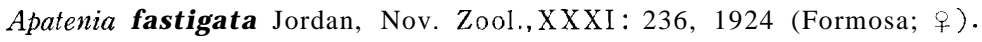

Oxyderes fastigata: Jordan, Nov. Zool., XXXIV: 114, 1928; Shibata, Ent. Rev. Japan, XV: 45, pl. 6, fig. 4, 1963 (Amami-Oshima, Mie, Tokushima) ; Shibata, Ent. Rev. Japan, XXXIV: 43, 1980 (Yaku, Kumamoto, Oita).

Specimens examined: Mt. Joyama, Munakata, Fukuoka Pref., 3ð, 9. vii. 1978, K. Kido leg. Mt. Hiko, Fukuoka Pref., 1우, 14. vii. 1954, H. Kamiya leg. Mt. Kumado, Fukuoka Pref., 1ㅇ, 17. vii. 1954, H. Ishibashi leg. Naidaijin, Kumamoto Pref., $1 \Im$, 26. vi. 1971, S. Naomi leg. Mt. Sobo, Oita Pref., 1 우, 27. vii. 1948, H. Doira leg. Mt. Ookue, Miyazaki Pref., 1 우, 28. vii. 1972, Y. Ota leg. Shiiya, Miyazaki Pref., 1, 27. vii. 1973, Y. Ota leg. Sata, Kagoshima Pref., 1 우, 24. v. 1962, Esaki \& Hirashima leg. Mt. Takatsuka, Yaku Is., 1 우, 21. vii. 1974, H. Irie leg. Lushan, Nantou Hsien, Taiwan, 1ð, 8. vi. 1976, H. Makihara leg.

Distribution: Japan (Honshu, Shikoku, Kyushu), Yaku Is., Amami-Oshima Is.), Taiwan. 


\section{Ulorhinus Sharp}

Ulorhinus Sharp, Trans. Ent. Soc. London,: 300, 1891 (Type-species: Ulorhinus funebris Sharp, by monotypy) ; Jordan, Nov. Zool., XXXIV: 121, 1928; Morimoto, Bull. Gov. Forest Exp. Sta., (246) : 45, 1972.

The generic definition given by Jordan (1928) is insufficient and new definition was given by me (1972) as:

Head not constricted behind eyes; penultimate segment of antennae broader than long; rostrum weakly depressed in the middle near the base ; basal margins of elytra marginate throughout from the side to scutellum.

For the last mentioned character, the channel along the basal margin of elytra is obsolete at the base of third and fourth intervals in U. gokani sp. nov. The antenna1 clubs of Ulorhinus spp. are not flattened, while in Oxyderes the clubs are flattened and longitudinally carinate in the middle.

\section{Ulorhinus funebris Sharp}

(Figs. 11, A-D; Photos e, f)

Ulorhinus funebris Sharp, Trans. Ent. Soc. London, : 301, 1891 (Chiuzenji).

Specimens examined: Misakubo, Shizuoka Pref., $1 \%$, 14. vii. 1954, K.Kojima leg. Mt. Hiko, Fukuoka Pref., $2 \gtrsim 3$ 우, 10. vii. 1938, Hori, Kawahara et Yasumatsu leg. Mt. Shojidake, Fukuoka Pref., 10, 18. viii. 1974, H. Irie leg. Mt. Homan, Fukuoka Pref., 13, 19. vi. 1962, Y. Miyatake leg. Mt. Kumado, Fukuoka Pref., 1 z, 2. viii. 1957, Y. Miyake leg. Mt. Katamuki, Oita Pref., 1 우, l-3. vii. 1957, K. Morimoto leg.

Distribution : Japan (Honshu, Kyushu).

\section{Ulorhinus gokani sp. nov.}

(Figs. 11, E-I; Photo g)

Male. Reddish brown to dark reddish brown, eyes black, with luteous grey and brownish pubescence. Head and rostrum with sparse luteous grey pubescence, which being denser around eyes; pronotum with a pair of greyish posts in the middle, luteous grey pubescence forming indistinct patches on side margins and a vague longitudinal short stripe in the middle, which widely interrupted at apex and in the middle; scutellum greyish; elytra in the odd numbered intervals tessellated with luteous grey and dark brown patches, the patches more distinct on third intervals, concolorously brownish in the even numbered intervals; pygidium and underside thinly with luteous grey pubescence, which being denser on prosternum, lateral pieces of meso- and metathorax; femora excepting the apex and bases of tibiae with sparse luteous grey pubescence, the remaining part of legs dark brown.

Head weakly depressed between eyes, strongly punctate, the interstices 

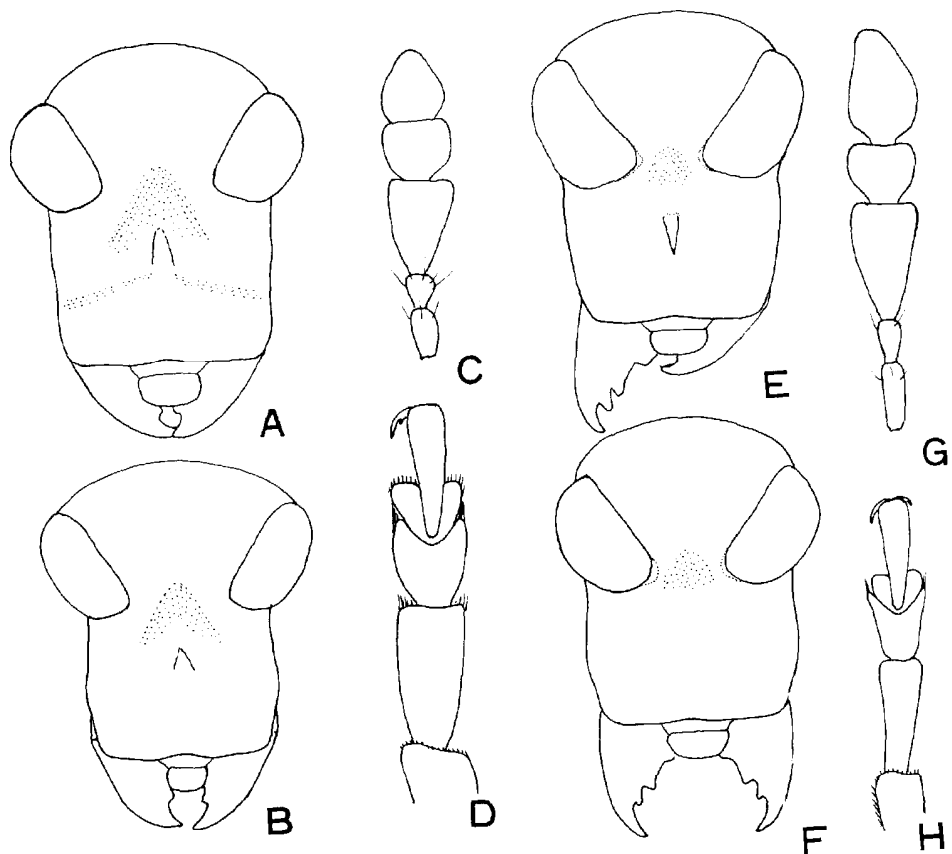

G

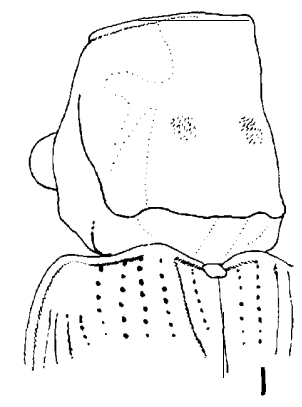

Fig. 11. Ulorhinus spp. A-D : funebris Sharp. (A : male head and rostrum. B : Ditto, female. C: Male antenna. D: Male front tarsus). E-I: gokani sp. nov. (E: Male head and rostrum. F: Ditto, female. G: Male antenna. H: Male front tarsus. I: Pronotum, latero-dorsal aspect).

between punctures as wide as the diameter, the narrowest distance between eyes $1 / 4$ the maximum width of rostrum; rostrum transverse (11: 7). slightly narrowing apically, anterior margin almost straight or weakly incurved in the middle, densely punctate, with or without a median short unpunctate carina; eyes almost twice as long as wide, strongly convergent anteriorly, marginate with glossy area around apex. Antennae reaching the base of pronotum, with proportions in length from base as $11: 10: 15: 11: 10: 9: 9: 5: 14: 7: 13$, eighth segment twice as long as wide, tenth segment as long as wide.

Pronotum as long as wide, widest a little before the middle, surface uneven, weakly depressed before the middle, weakly convex at the grey spots and behind the middle, strongly punctate as on head, the punctures being smaller anteriad and obsolete at the dorso-apical margin, dorsal carina trisinuate, slightly and narrowly convex in the middle, evenly and widely convex anteriorly parallel to the base of elytra, roundly connate to lateral carinae, the latter sinuate and reaching to apical third, Iongitudinal carinulae weak, not connate but ending below the base of lateral carinae.

Scutellum transverse oval.

Elytra subparallel on basal three-fourths, basal margin strongly convex on 
pronotum, basal margination obsolete at the base of third and fourth intervals, first, second and fourth intervals flat, third intervals widest, weakly convex, the remaining intervals slightly convex, subbasal swellings weak, subapical swellings obsolete.

Pygidium as long as wide, tongue-shaped, side margins sharply carinate and shiny, with a median sulcus on basal third, weakly and roundly convex behind the middle.

Pro- and mesosternum strongly punctate. Metasternum with post-coxal sulcus deep and entire, median narrow black carina convex to form a denticle at basal third, lateral surface of metasternum strongly punctate. Venter punctulate, weakly depressed in the middle of four basal segments.

Legs with hind tibiae weakly incurved; claws toothed in both sexes as in funebris.

Female. Forehead between eyes about $1 / 3$ times as wide as rostrum. Venter not depressed, fifth ventrite bent downwards in the median third forming a transverse rectangular short protrusion at posterior margins, its apical margin on the same level as the apex of pygidium, which with a median sulcus in entire length, weakly depressed along margins. Tibiae not incurved. Length : 6.8-7.5 mm (excl. head).

Holotype $\sigma^{\lambda}$ (Type No. 2311, Kyushu Univ.) and paratypes $1 \gtrsim 1$ 우, Kirizumi, Gunma Pref., 10. vii. 1960, N. Gokan leg.

Distribution : Japan (Honshu).

This new species is easily separable from funebris Sharp as follows: funebris: Black, pronotum widest at lateral angles of carina, pygidium almost

flat, tarsi broader, 4.0-5.1 $\mathrm{mm}$ in length.

gokani: Reddish brown to dark reddish brown, pronotum widest at a little before the middle, pygidium uneven, tarsi slender, 6.8-7.5 $\mathrm{mm}$ in length.

\section{Aphaulimia Morimoto}

Aphaulimia Morimoto, Bull. Gov. Forest Exp. Sta., (246): 35, 1972 (Type-species : Tropideres debilis Sharp, by original designation).

\section{Aphaulimia debilis (Sharp)}

(Fig. 12; Photos h, i)

Tropideres debilis Sharp, Trans. Ent. Soc. London: 311, 1891 (Junsai, Chiuzenji).

Hypseus debilis: Morimoto, Sci. Bull. Fac. Agr. Kyushu Univ., 19: 164, 1962 ; Nakane, Icon. Ins. Jap. col. nat. ed. II: 352, pl. 176, fig. 24, 1963.

Phaulimia debilis: Shibata, Ent. Rev. Japan, XVI: 3-4, pl. 1, fig. 4, 1963 (Nagano, Wakayama, Tottori, Tokushima, Oita, Kagoshima).

Aphaulimia debilis Morimoto, Bull. Gov. Forest Exp. Sta., (246) :35, fig. 98, 1972 (devilis!). 


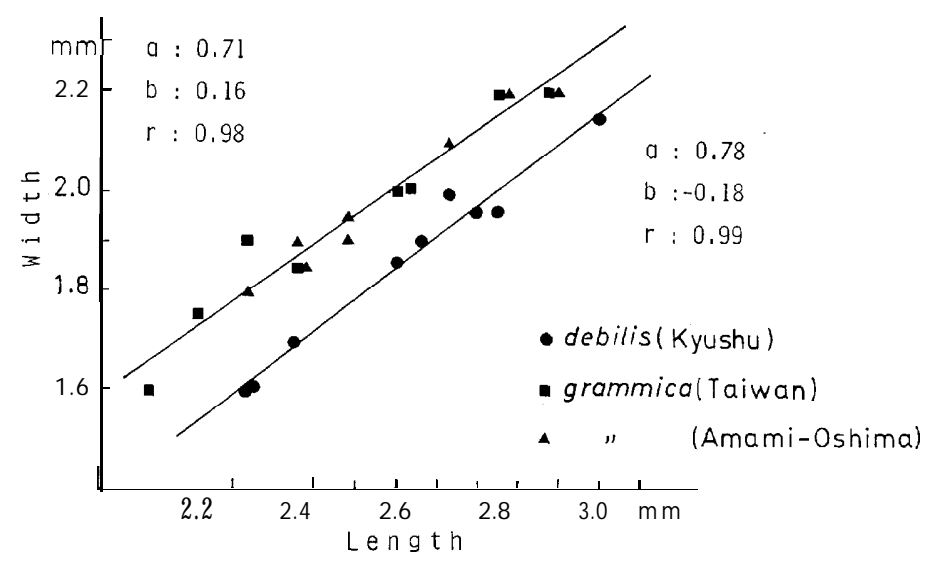

Fig. 12. Aphaulimia debilis (Sharp) and grammica (Jordan), the width of elytra plotted against its maximum length. a, b: constants in the formula $\mathrm{Y}=\mathrm{ax}+\mathrm{b}$.

Specimens examined: 33 specimens from Shizuoka Pref. (Misakubo), Wakayama Pref. (Koya), Kochi Pref. (Kitagawa, Mt. Tebako, Matsubakawa, Makiyama), Fukuoka Pref. (Mt. Fukuchi, Mt. Hiko), Oita Pref. (Mt. Sobo), Kumamoto Pref. (Naidaijin), Kagoshima Pref. (Shiroyama, Cape Sata), Tsushima, Yaku Is. ( Miyanoura, Hirano, Shiratani), Meshima Is. and Kuroshima Is.

Distribution: Japan (Hokkaido, Honshu, Kyushu, Tsushima, Yaku Is., Meshima Is., Kuroshima Is.).

The specimens from Cape Sata, Yaku, Kuroshima, Meshima and Tsushima are very close to grammica Jordan in scaly markings with many luteous lines on elytra, and often completely enclosing the lateral brown spots by greyish patches.

\section{Aphaulimia grammica (Jordan)}

(Fig. 12; Photo j)

Phaulimia grammica Jordan, Nov. Zool., XIX: 142, 1912 (Formosa) ; Shibata, Ent. Rev. Japan, xvI : 3, pl. 1. fig. 3, 1963 (Amami-Oshima, Nakanoshima).

SPecimens examined : 50 specimens from Taiwan (Nanshanchi, Lushan, Tihyuehtan, Chulu), Iriomote Is., Ishigaki Is., Okinawa Is. and Amami-Oshima Is.

Distributron: Japan (Nakanoshima, Amami-Oshima, Okinawa, Ishigaki and Iriomote Isls.), Taiwan.

Key to J apanese species of the genus Aphaulimia Morimoto

1 : Tibiae, especially hind ones, each with a greyish subbasal greyish ring; antennae with seventh segment 1.2-1. 3 times as long as eighth; venter 
with fifth ventrite flattened and pubescent in the middle in male; body

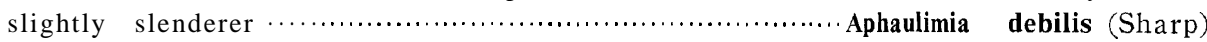
1': Tibiae without distinct ring; antennae with seventh segment hardly longer than eighth; fifth ventrite with two tubercles in male; body robuster .........

Aphaulimia grammica (Jordan)

\section{Habrissus Pascoe}

Habrissus Pascoe, Ann. Mag. Nat. Hist., (3)IV: 432, 1859 (Type-species : Habrissus pilicornis Pascoe, by monotypy) ; Morimoto, Bull. Gov. Forest Exp. Sta., (246) : 45, 1972.

The genus Habrissus comprises rather heterogeneous species at present.

The typical species of the genus are larger, their antennae are slender with very long setae, the pronotum is widest at side angles of carina and rapidly narrowing anteriorly, the dorsal carina is straight and rounded at sides, the lateral carinae are short, the carinulae are absent, the rostrum has a median and a pair of lateral carinae, and the metasternum is simple in the male.

The unciferoides-pardalis group comprises also formosanus Jordan, and probably inducus Jordan, tonkinianus Jordan and tibialis Jordan. They have a characteristic file-like velvety structure on the metasternum in the male. They are generally robust in shape, their antenna1 clubs are usually much wider than funicle, and the rostrum has at most a median carina. The dorsal carina of pronotum is almost straight and narrowly rounded at sides, and the carinulae are often incomplete or complete. This group resembles to Apatenia, but the dorsal carina is much closer to elytra and the side margins of pronotum behind the angles of carinae are narrowing posteriorly.

The longipes group is close to above, but the dorsal carina is evenly concave and widely rounded at sides, and the carinulae are absent. The rostrum has a median and a pair of lateral carinae.

The cylindricus-nigronotatu group is characteristic in the male, which has a comb-like structure on the middle femora, similar but short structure is also found at the apex of middle tibiae in male. The pronotal carina is straight and angulately rounded at sides, the lateral carinae are rather long and reaching at least to the basal third.

Habrissus pardalis (Sharp), comb. nov.

(Photo p)

Tropideres pardalis Sharp, Trans. Ent. Soc. London,: 313, 1891 (Sapporo, Junsai). Hypseus pardalis: Morimoto, Sci. Bull. Fac. Agr. Kyushu Univ., 19: 164, 1962.

Specimens examined: Daibosatsu, Yamanashi Pref., 1 우, 27. vii. 1969, T. Akashi leg. Mizukami-mura, Kumamoto Pref., 1ð, 6. viii. 1958, T. Tahara leg. Distribution : Japan (Hokkaido, Honshu, Kyushu). 

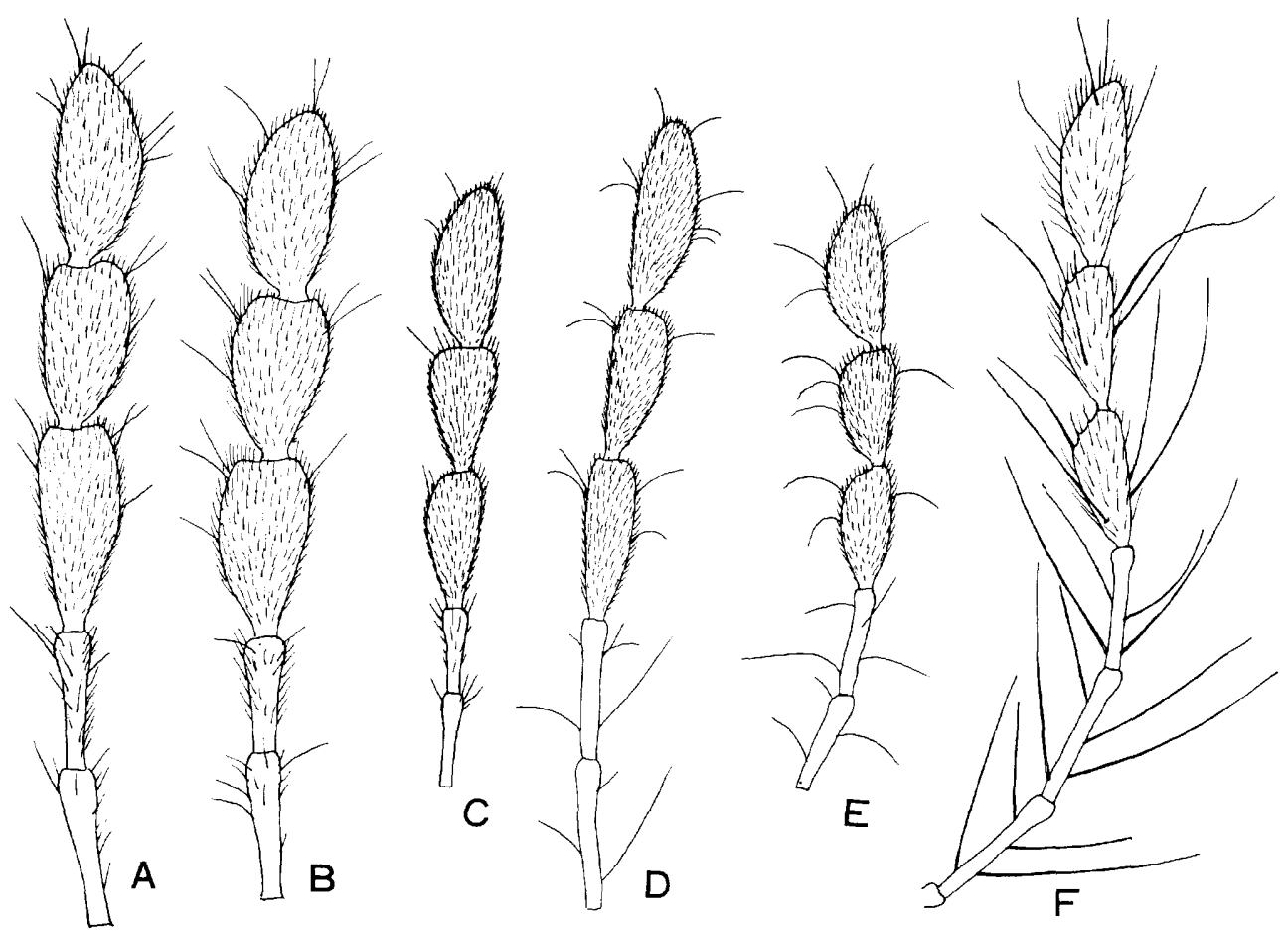

Fig. 13. Habrissus spp., antenna. A: longipes (Sharp), male. B: Ditto, female. C: analis sp. nov., male. D: formosanus Jordan, male. E: Ditto, female. F: nigronotatus sp. nov., male.

Habrissus unciferoides (Nakane), comb. nov.

(Photo o)

Hypseus unciferoides Nakane, Fragm. Col., (8) : 31, 1963 (Cape Sata); Nakane, Icon. Ins. Jap. col. nat. ed. II: 350, pl. 175, fig. 25, 1963.

Phaulima pardalis: Anonym (nec Sharp), Icon. Ins. Jap. col. nat. ed., II, Addenda et corrigenda: $17,1978$.

Specimens examined : Yunohana, Fukushima Pref., 46, 25. viii. 1970, T. Akas hi leg. Mt. Kai-koma, Yamanashi Pref., 1 우, 13. viii. 1962, K. Oshima leg. Obina-yama, Kofu City, 1 ㅇ, 28. vii. 1958, H. Kamiya leg.C ape Ashizuri, Kochi Pref., $1 \delta^{ð}$,27. v. 1966, H. Nakamura leg. Mt. Hiko, Fukuoka Pref., 1우, 9. vi. 1957, K. Yasumatsu leg. ;1 i, 21. vii. 1970, S. Ogata leg. ;1 क, 23. vi. 1974, H. Irie leg. Mt. Homan, Fukuoka Pref., 2ㅇ, 5. vi. 1971, H. Irie leg. Mt. Kumado Fukuoka Pref., 1 ㅇ, 9. vi. 1957, H. Ishibashi leg. Mt. Sobo, Oita Pref., 1 우, 29. vi. 1932, Hori, Fujino \& Cho leg. ; 1 ; , 2. vii. 1932, Hori, Fujino \& Cho leg. Kikuchi-suigen, Kumamoto Pref., la, 30. vi. 1974, S. Ogata leg. Ashikita, Kumamoto Pref., $1 \curvearrowright, 28$. v. 1977, Y. Imakiire leg. Hitoyoshi, Kumamoto Pref., $1 \jmath^{\nwarrow}$,28.v. 1971, H. Makihara leg. Mt. Shiroiwa, Miyazaki Pref.,1ð1우, 25. vii. 

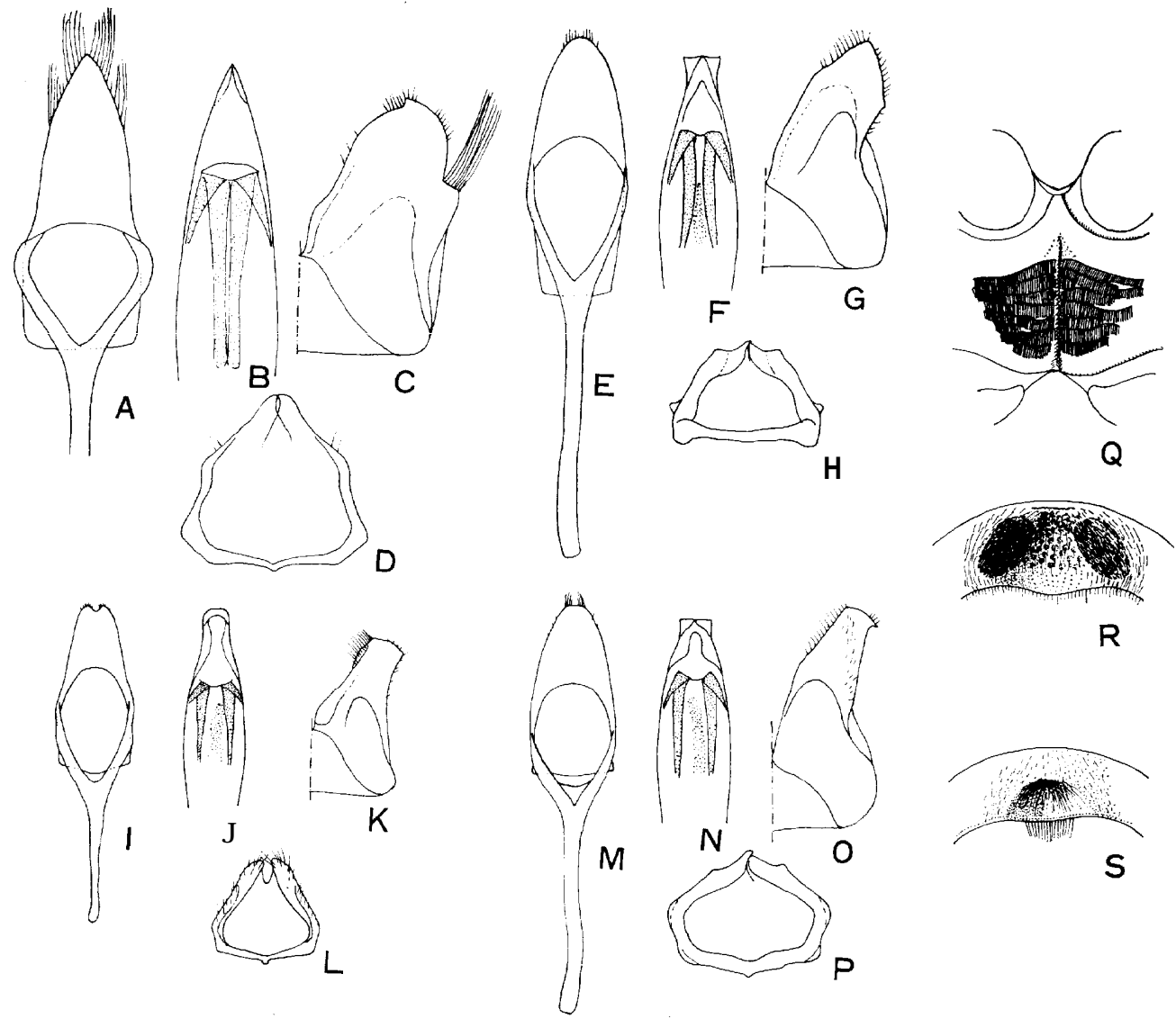

$\mathbf{R}$

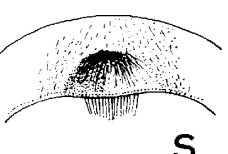

Fig. 14. Habrissus spp. A, E, I, M: Tegmen. B, F, J, N: Apical part of penis. C, G, K, 0: Tergite of genital segment, right half. D, H, L, P: Sternite of genital segment. Q: File-like structure of metasternum in male. $\mathrm{R}, \mathrm{S}$ : Fifth ventrite in male. A-D: nigronotatus sp. nov. E-H, Q, R : analis sp. nov. I-L: formosanus Jordan. M-P, S: longipes (Sharp)

1974, H. Irie leg. Mt. Takachiho, Kagoshima Pref., 1우, 13. vi. 1958, H. Maebara leg.; 1 , 23. v. 1969, H. Makihara leg. (from dead twig of Abies firma). Shidoshi, Yaku Is., 1ð, 17. vi. 1974, H. Irie leg.

Distribution: Japan (Honshu, Shikoku, Kyushu, Yaku Is.).

\section{Habrissus formosanus Jordan, status nov.}

(Figs. 13, D; 14, I-L ; Photo s)

Habrissuslongipes formosanus Jordan, Nov. Zool., XIX: 143, 1912 (Formosa).

Specimens examined : Yona, Okinawa, 1 우, 22. v. 1965, K. Morimoto leg.; 1 万우, 12-17. vi. 1970, H. Makihara leg. Mt. Yonahadake, Okinawa, $1 \precsim, 24$. iv. 1973, H. Irie leg. ;2우, 21. v. 1976, T. Ogasawara leg. Oku, Okinawa, 1 우, 
16. v. 1976, T. Ogasawara leg. ; 1 우, 15. v. 1978, H. Makihara leg. Taminato, Okinawa, 2 우, 23. iv. 1973, H. Irie leg. Mt. Omotodake, Ishigaki, 1우, 7. vi. 197.2, H. Irie leg. ; 1 , 3. iv. 1973, H. Irie leg. ; 1 ㅇ, 15. iv. 1973, H. Irie leg. ; $1 \precsim 2$ ㅇ, 3-7. v. 1974, H. Irie leg.; $6 \precsim 3$, 20-27. v. 1974, H. Irie leg. ; 1 ॠ 21 . iv. 1975, H. Irie leg.;1, 25. v. 1976, H. Irie leg. ; 16, 19. vi. 1977, H. Irie leg. Nakara Riv., Iriomote, 1 , 25. vi. 1970, H. Makihara leg. Shirahama, Iriomote, $1 \precsim$, 9. vi. 1972, H. Irie leg. Wulai, Taiwan, 1 ㅇ, 27. v. 1965, K. Morimoto leg. Nanshanchi, Nantou Hsien, Taiwan, 1 우, 26. v. 1965, T. Shirôzu leg. ;1우, 16. v. 1971, K. Sakai leg. Penpuchi, Nantou Hsien, Taiwan, 2 ə 2 , 9. vii. 1966, H. Sasaji leg. Lushan Wenchuan, Nantou Hsien, 1우, 6. vi. 1976, H. Makihara leg. ; 239 , 27-29. v. 1980, H. Makihara leg. Suleng, Taoyuan Hsien, Taiwan, 1 우, 22-23. v. 1980, H. Makihara leg.

Distribution: Japan (Okinawa, Ishigaki and Iriomote Isls.), Taiwan.

\section{Habrissus longipes (Sharp)}

(Figs. 13, A, B; 14, M-P, S; Photo q)

Tropideres longipes Sharp, Trans. Ent. Soc. London,: 31'2, 1891 (Junsai, Sapporo, Chiuzenji). Ulorhinus funebris Iga (nec Sharp), Col. Ill. Ins. Jap., Col. : 136, pl. 49, fig. 6, 1954.

Habrissus longipes: Jordan, Nov. Zool., XIX : 143, 1912; Iga, Col. Ill. Ins. Jap., Col., enlarged \& rev. ed. : 352, pl. 61, fig. 1343, 1955; Nakane, Icon. Ins. Jap. col. nat. ed., II : 352, pl. 176, fig. 27, 1963.

Specimens examined: 47 specimens from Hokkaido (Sapporo, Mt. Muine), Aomori Pref. (Shimokita, Towada), Fukushima Pref. (Yunohana), Tochigi Pref. (Nikko), Fukui Pref. (Koike), Yamanashi Pref. (Mt. Fuji), Kochi Pref. (Kuroson), Ehime Pref. (Mt. Ishizuchi), Fukuoka Pref. (Mt. Hiko, Mt. Fukuchi, Mt. Kumado), Oita Pref. (Mt. Sobo), and Miyazaki Pref. (Ookawachi).

Distribution: Japan (Hokkaido, Honshu, Shikoku, Kyushu).

\section{Habrissus analis sp. nov.}

(Figs. 13, C ; 14, E-H, Q, R; Photo r)

Male. Black, antennae except for clubs, tarsi with third and fourth segments and mouth parts reddish brown; dorsal surface variegated with blackish and greyish to brownish grey pubescence, the latter forming following patches, head with seven indistinct patches, one pair below eyes, one pair along inner margin of eyes, one pair behind the postero-inner margin of eyes, and one at the center of vertex; pronotum with several indistinct patches, one before scutellum and a pair behind transverse carina usually distinct, median and a pair of lateral stripes widely interrupted in the middle, and with two pairs of indistinct patches arranged transversely in the middle; scutellum densely pubescent; elytra with the odd-numbered and fourth intervals with 
greyish to brownish grey spots behind the middle, which conjointly forming larger patches on third to fifth intervals; femora thinly clothed with greyish longer pubescence, hind femora each with a distinct ring at apical fourth, both side of the ring often brownish ; tibiae each with a median ring; tarsi with basal half of first and entire surface of second segments greyish; undersurface sparsely covered with greyish longer pubescence except for mesosternum.

Head densely punctate, forehead between eyes much narrower than rostrum $(5: 11)$; rostrum transverse, densely punctate, with three carinae on basal half, median carina extending posteriorly to vertex, lateral carinae weak and slightly convergent anteriorly from the inner margin of eyes. Antennae slender, with proportions in length from base as $10: 10: 16: 13: 12: 11: 11: 9: 14$ : $14: 15$, width of tenth 6 , club asymmetric.

Pronotum a little wider than long $(8: 7)$, the sides evenly rounded, transverse carina as in longipes, weakly concave posteriorly, widely rounded on each side and continued to very short lateral carinae, carinulae absent, disk densely punctate.

Elytra as in longipes, third and fourth intervals wider and slightly convex.

Pygidium a little wider than long, the sides straight and weakly narrowing postreiorly, posterior margin subtruncate, slightly depressed along side margins, punctate.

Prosternum before coxae and lateral areas of metasternum sparsely provided with large punctures, mesosternal process and venter with small sparse punctures. Venter with fifth ventrite deeply excavated in the middle, each side of the excavation with a blackish velvety patch.

Aedeagus with penis evenly narrowing apically from the middle and weakly dilated at apex, truncate at tip; cap-piece of tegmen rounded at apex ; tergite of genital segment obliquely truncate at apex, sternite not hairy.

Female. Antennae slightly shorter, with proportions in length from base as $12: 9: 14: 12: 10: 9: 10: 8.5: 18: 11: 14$, width of tenth 7 . Venter with fifth ventrite simple, slightly protruding ventrad.

Length : 4.9-8. $0 \mathrm{~mm}$ (excl. head).

Holotype (Type No. 2312, Kyushu Univ.), Shiiya-toge, Miyazaki Pref., 31. vii. 1977, H. Irie leg.

Paratypes: Mt. Shiroiwa, Miyazaki Pref., 2 1우, 25-26. vii. 1974, H. Irie leg. Mt. Ariake, Tsushima, 1 우, 12. vii. 1960, H. Kamiya leg. Mt. Tatera, Azamo, Tsushima, $1 \precsim$, 13. vii. 1960, H. Kamiya leg. Mt. Ohoshi, Tsushima, $1 \precsim$, 15. vii. 1960, H. Kamiya leg.

Distribution : Japan (Kyushu, Tsushima).

This new species is very close to longipes (Sharp), but the male is easily recognized by the structure of the fifth ventrite. 


\section{Habrissus nigronotatus sp. nov.}

(Figs. 13, F ; 14, A-D; Photos k, 1)

Male. Black, antennae and mouth parts reddish brown, legs dark reddish brown; densely covered with ochreous grey pubescence mixing blackish ones, the latter forming following patches: pronotum with several indistinct small patches, often with large denude patches on sides ; elytra with a pair of large quadrate median patches on second to fifth intervals, with a few small spots on first and fifth intervals before the middle, and a small spots on seventh and ninth intervals, one spot each on humeral callus and above metepimeron, and with a pair of subbasal patches on second to fifth intervals and a pair of transverse patches on the declivity of second to fourth intervals.

Head densely punctate, forehead between eyes one-third as wide as rostrum ; eyes weakly emarginate behind antenna1 scrobes; rostrum twice as wide as long, densely punctate, median carina weak, extending from the anterior margin to forehead or often the carina absent. Antennae slender, each segment from the third to apex with a few very long setae, with proportions in length from base as $6: 6: 17: 12: 10: 9: 9: 8: 7: 7: 9$, width of tenth 3 .

Pronotum transverse ( $3: 4)$, widest at the lateral angles of carina, punctures sparser and smaller than those on head, transverse carina run parallel to the base of elytra and almost rectangularly connate to lateral carinae, which extending anteriorly to the middle, carinulae absent.

Elytra with punctured striae not lower than intervals, subbasal swellings indistinct, basal margin weakly convex anteriorly, slightly depressed transversely behind the base.

Pygidium as in analis.

Underside punctured as in analis. Metasternum without a file-like structure.

Middle femora each with a comb-like structure along posterior margin behind the middle formed of a row of yellowish stout spines, similar but short structure present at apex of middle tibiae. Venter slightly flattened in the middle.

Aedeagus with penis sharply pointed ; cap-piece of tegmen pointed; tergite of genital segment weakly hooked at apex, with a hair tuft at side.

Female. Forehead between eyes half as wide as rostrum. Venter not flattened, fifth ventrite slightly protruding ventrad.

Length : 4.7-5.6 mm (excl. head).

Holotype 8 (Type No. 2313, Kyushu Univ.), Yoshihara, Ishigaki, 18. vi. 1977, H. Irie leg.

Paratypes: Same locality as holotype, 1 우,2. iv. 1973, H. Irie leg. ;1주 1 우, 27. iv. 1974, H. Irie leg.; 2 우, 17. v. 1974, H. Irie leg. ; 1 1우, 17-18. vi. 1977, H. Irie leg. Yonehara, Ishigaki, 1 ㅇ, 22. v. 1975, T. Nakane leg. ;1 1 우, 28. v. 
1977, T. Ogasawara leg. Zaisho, Minami-Daito Is., $1 \precsim, 10$. v. 1978, T. Tsutsumi leg. Mt. Yuwandake, Amami-Oshima, 1 q, 17. vii. 1963, Y. Kurosawa leg.

Distribution: Japan (Amami-Oshima, Okinawa, Ishigaki, and MinamiDaito Isls.).

\title{
Habrissus cylindricus (Sharp), comb. nov.
}

\author{
(Photos m, n)
}

Tropideres cylindricus Sharp, Trans. Ent. Soc. London,: 311, 1891 (Nagasaki, Nara, Junsai, Oyama).

Hypseus cylindricus: Morimoto, Sci. Bull. Fac. Agr. Kyushu Univ., 19: 164, 1962; Nakane, Icon. Ins. Jap. col. nat. ed., II: 352, pl. 176, fig. 23, 1963.

Phaulimia cylindricus : Anonym, Icon. Ins. Jap. col. nat. ed., II, Addenda et corrigenda: 17, 1978.

Specimens examined: Moiwayama, Hokkaido, 1 , 14. vii. 1976, H. Irie leg.

Mt. Hiko, Fukuoka Pref., 1 $\frac{+}{16}$. vii. 1954, H. Kamiya leg. Mt. Joyama, Munakata, Fukuoka Pref., 1 우, 6. vi. 1964, K. Kido leg.

Distribution : Japan (Hokkaido, Honshu, Kyushu).

\section{Key to Japanese species of the genus Habrissus Pascoe}

1: Middle femora each with a comb-like structure formed of a row of stout spines on posterior margin behind the middle in male; antennae with very long setae; pronotal carina parallel to the base of elytra and angulate or nearly angulate at sides, lateral carinae present at least on basal third, lon-

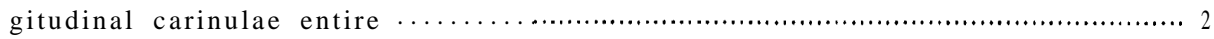

1': Femora simple; male with a blackish file-like structure on metasternum; antennae with short setae; pronotal carina rounded at sides, lateral carinae very short, not passing anteriorly beyond the basal third.

2 : Body length 2.8-4.5 $\mathrm{mm}$ (excl. head), dark reddish brown to blackish brown, legs pale red, elytra reddish at sides and nearly blackish about the suture, rostrum not carinate, flat, elytra straight at base ........ Habrissus cylindricus (Sharp)

2': Body length 4.7-5.6 mm (excl. head), black with dark reddish brown legs, with distinct blackish patches, elytra weakly arched anteriorly at base, rostrum with a median carina $\ldots \ldots \ldots \ldots \ldots \ldots \ldots \ldots \ldots \ldots \ldots \ldots \ldots \ldots \ldots \ldots$ Habrissus nigronotatus sp. nov.

3: Dorsal pronotal carina almost straight, narrowly rounded at sides, lateral carinae reaching nearly to the basal third....

3': Dorsal pronotal carina evenly concave and widely rounded at sides, lateral carinae very short, carinulae absent, antennae with short setae, fifth ventrite in male with a median depression and with one or two velvety black spots on the anterior wall of the depression, elytra with smaller greyish

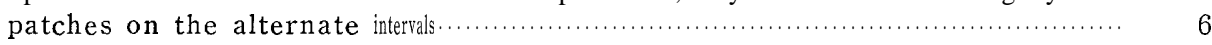

4 : Pronotum strongly transverse, 1.5 times as wide as long; elytra convex anteriorly at base

$4^{\prime}$ : Pronotum 1.2 times as wide as long, elytra almost straight at base ............

5: Tarsi with first segment greyish on basal half; derm dark reddish brown to brownish black, elytra variegated with blackish brown and greyish patches, 
blackish brown patches forming broad basal, median and often postmedian bands …............................................... Habrissus unciferoides (Nakane)

5': Tarsi with first segment greyish on basal three-fourths, derm black with ash-grey patches on dorsal and apical areas ................. Habrissus pardalis (Sharp)

6: Male with fifth ventrite deeply excavated in the middle and with a pair of black velvety patches at antero-lateral wall of the excavation; antennae with third segment distinctly longer than the fourth ........ Habrissus analis sp. nov.

6': Male with fifth ventrite triangularly depressed in the middle on posterior half, anterior margin of the depression with a transverse narrow blackish velvety patch; antennae with third segment scarcely longer than the fourth

Habrissus longipes (Sharp)

\section{Explanation of photographs}
A. Nerthomma aplota Jordan, Amami-Oshima.
B. Autotropis okinawanus sp. nov., holotype, Okinawa.
C, D. A utotropis basipennis (Sharp). C: Yamanashi, D: Holotype.
E. Uncifer pectoralis (Sharp), holotype, Junsai.
F. Uncifer bruchoides (Sharp), holotype, Kashiwagi.
G. Uncifer difficilis (Sharp), holotype, Fukushima.
H. Uncifer truncatus (Sharp), holotype, Kashiwagi.
I. Rhaphitropis imperfectus (Sharp), holotype, Nagasaki.
J. Rhaphitropis guttifer (Sharp), holotype, Nagasaki.
K. Rhaphitropis concolor (Sharp) (=guttifer), holotype, Yokohama.
L. Exechesops leucopis (Jordan), holotype, Tonkin.
M. Gibber incisus (Sharp), holotype, Ichiuchi.
$\mathrm{N}$, 0. Gibber nodulosus (Sharp). N: Holotype, Kiga. 0: Aomori.
P, Q. Gibber brevirostris (Sharp). P : Holotype, Sapporo. Q : Yamanashi.
R, S. Gibber ogasawarensis sp. nov., paratypes, Hahajima.
T, U. Phaulimia confinis (Sharp). T: Holotype, Hitoyoshi. U: Fukuoka.
V, W. Phaulimia aberrans (Sharp). V: Holotype, Junsai. W: Miyazaki.
$\mathrm{X}$. Phaulimia decorata (Shibata), Amami-Oshima.
Y. Phaulimia incerta (Shibata), Ishigaki.
Z. Phaulimia rufobasis sp. nov., paratype, Kanagawa.
a. Phaulimia minor Shibata, Hahajima.
b. Phaulimia annulipes sp. nov., holotype, Hahajima.
c. Phaulirnia angusta sp. nov., paratype, Ishigaki.
d. Oxyderes fastigata (Jordan), Fukuoka.
e, f.Ulorhinus funebris Sharp. e: Holotype, Chiuzenji. f: Fukuoka.
g. Ulorhinus gokani sp. nov., holotype, Gunma.
h, i. Aphaulimia debilis (Sharp). h : Holotype, Junsai. i : Yaku.
$\mathrm{j}$ : Aphaulimia grammica (Jordan), Ishigaki.
$\mathrm{k}$, 1. Habrissus nigronotatus sp. nov. $\mathrm{k}$ : Holotype. 1 : Paratype. Ishigaki.
$\mathrm{m}$, n. Habrissus cylindricus (Sharp). m: Holotype, Oyama. n : Sapporo.
o. Habrissus unciferoides (Nakane), Kumamoto.
p. Habrissus pardalis (Sharp), Yamanashi.
q. Habrissus longipes (Sharp), holotype, Junsai.
$\mathrm{r}$. Habrissus analis sp. nov., holotype, Miyazaki.
s. Habrissus formosanus Jordan, Okinawa. 
ANTHRIBIDAE OF JAPAN

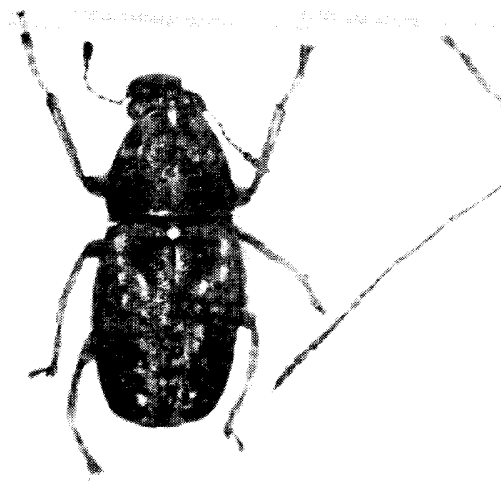

B

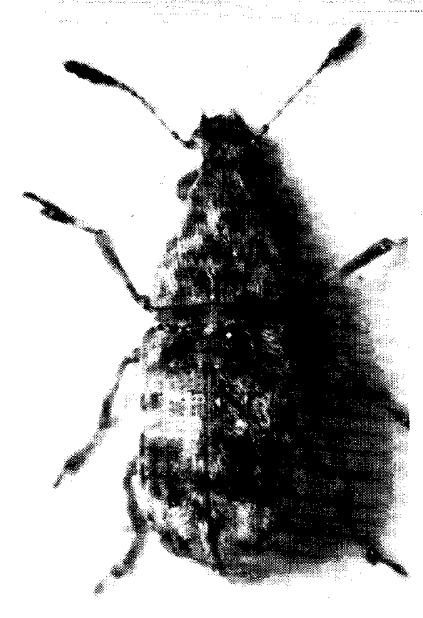

D

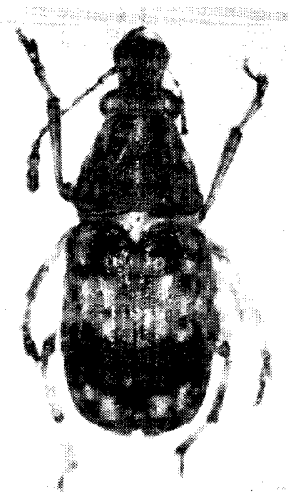

A

C

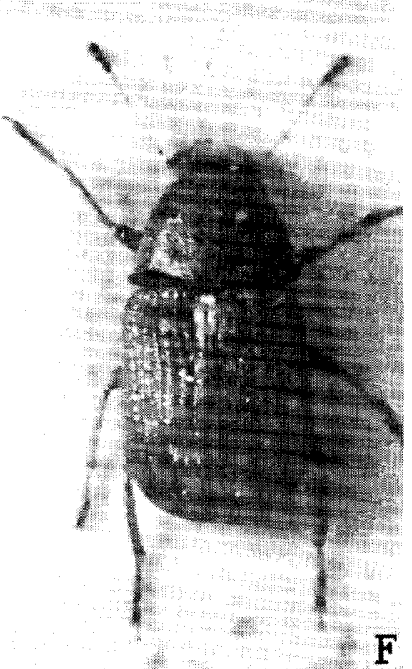

$-\quad E$

F
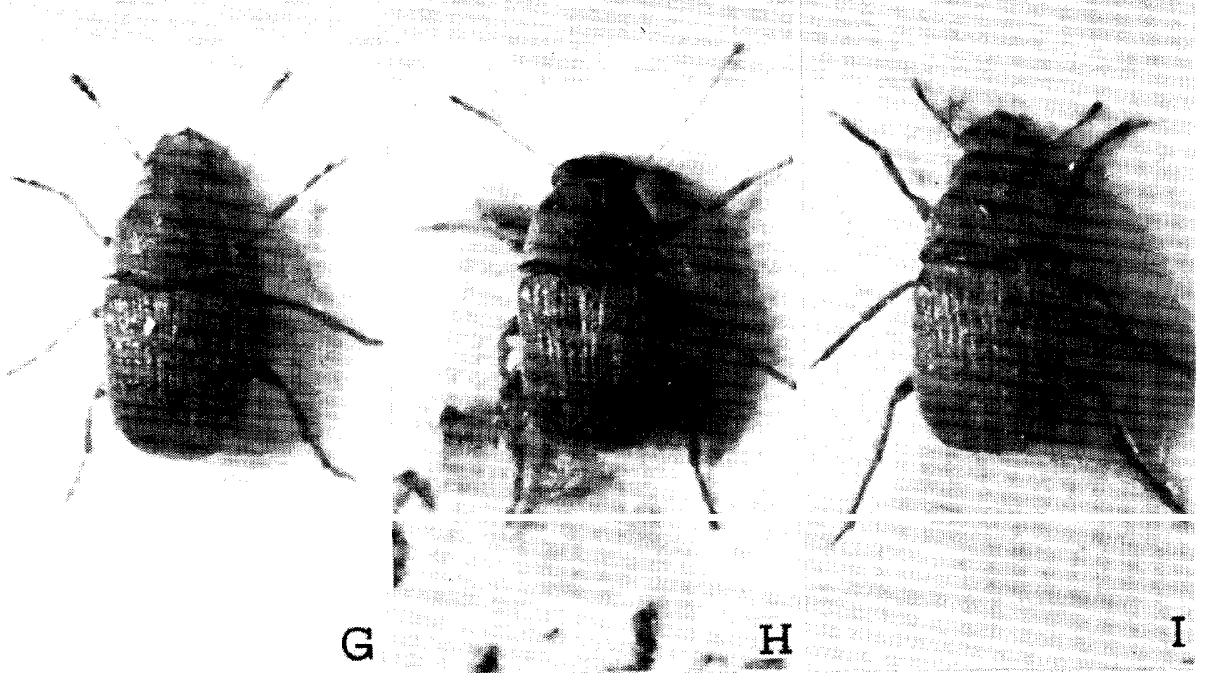


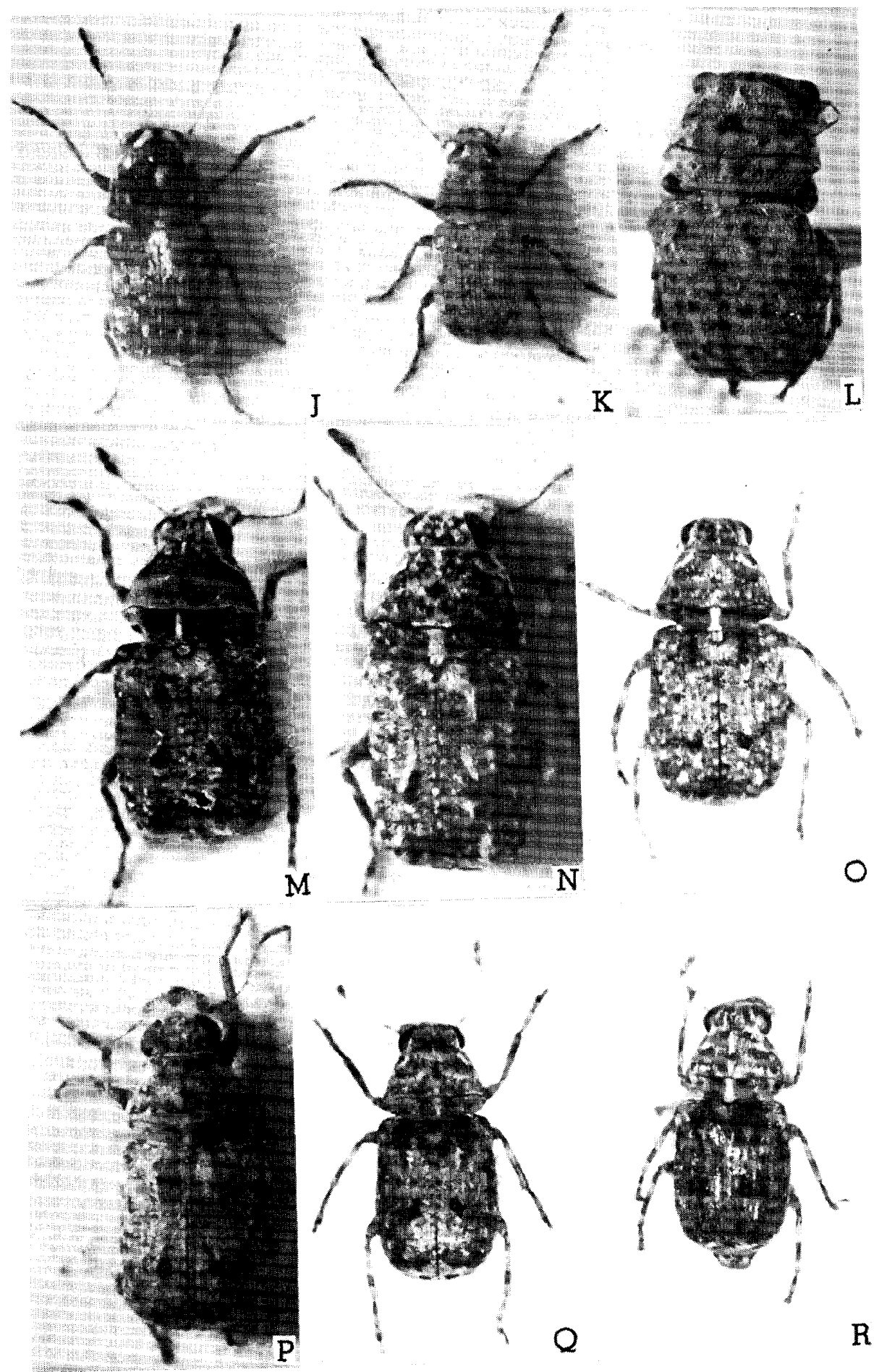



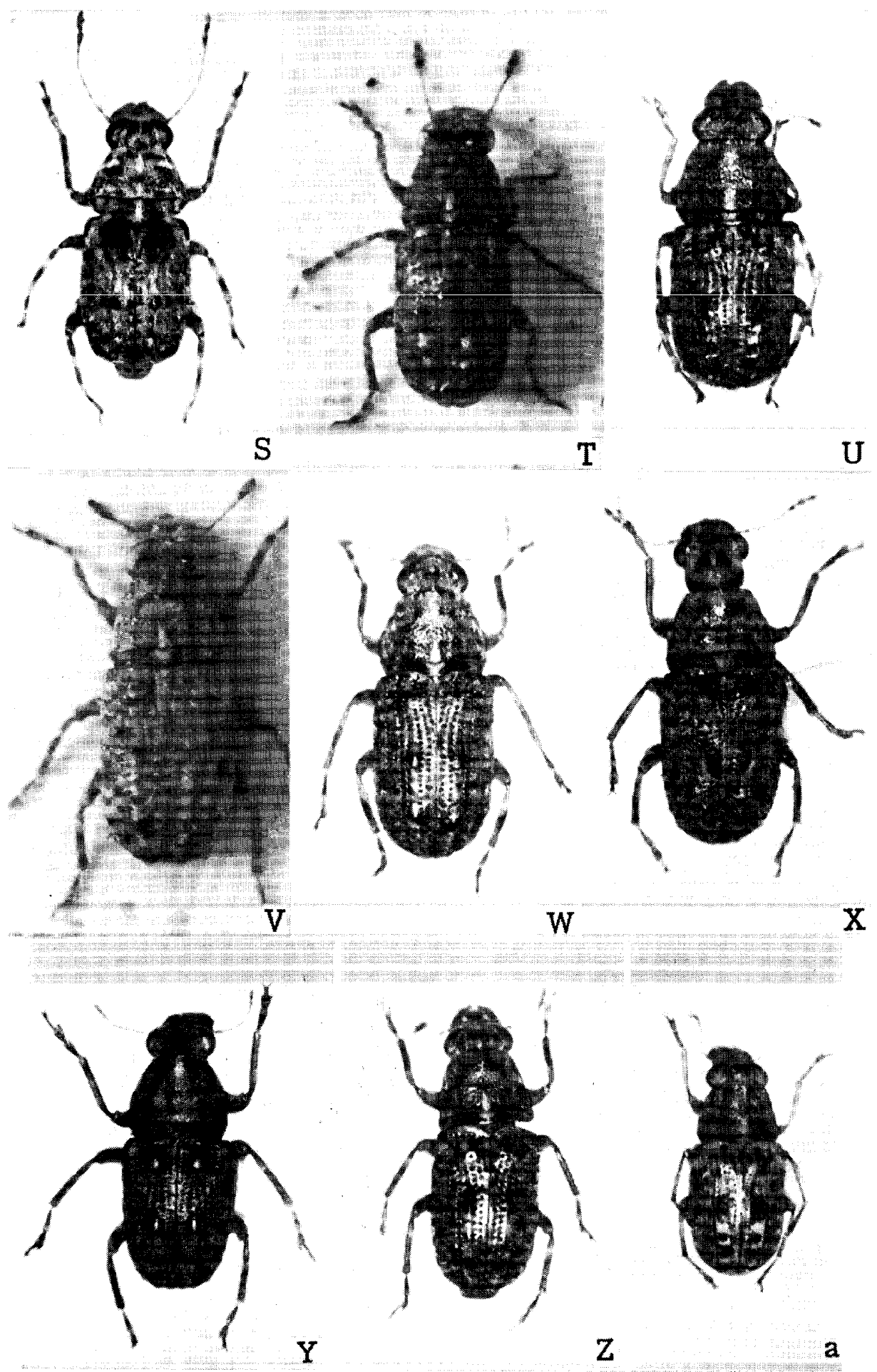


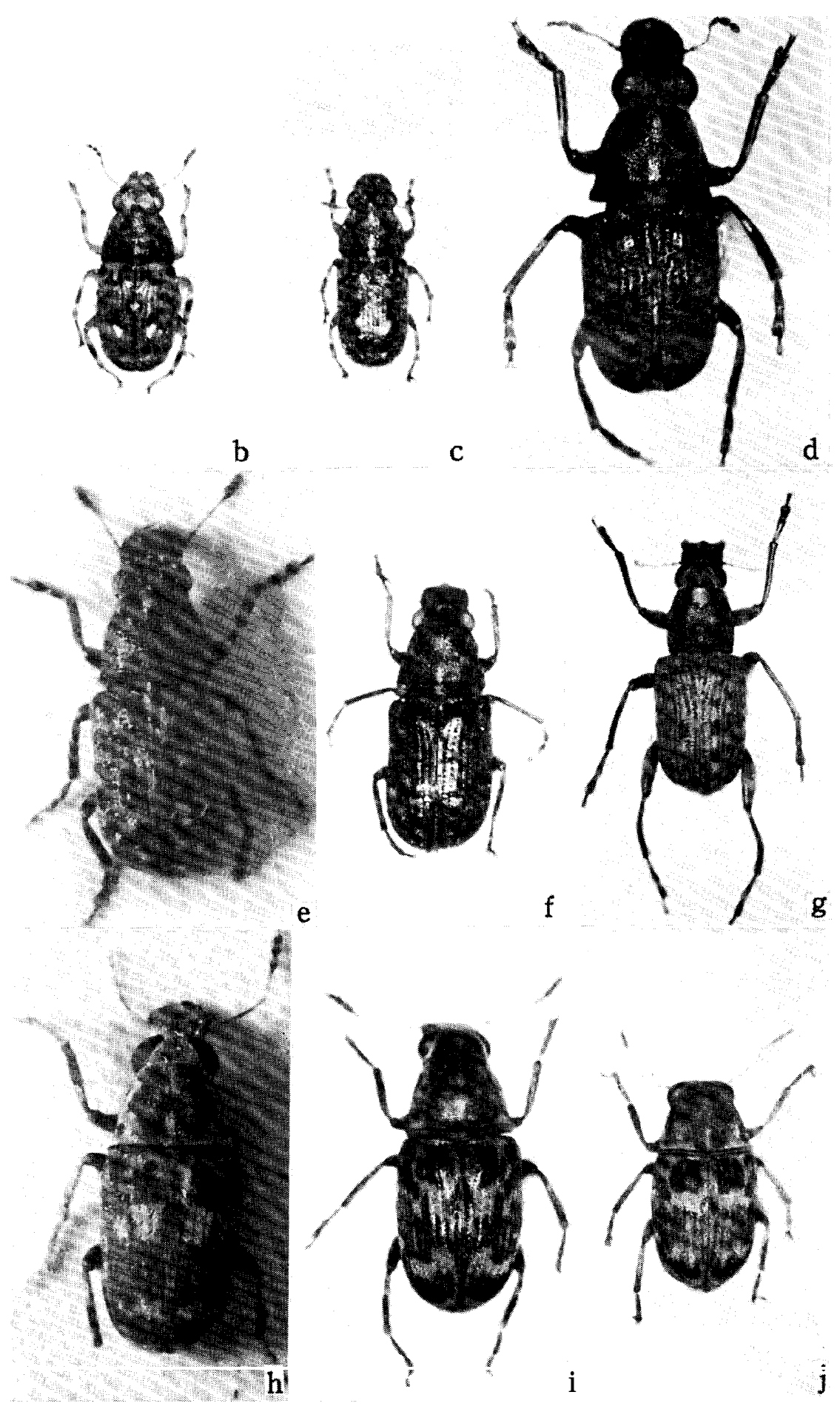



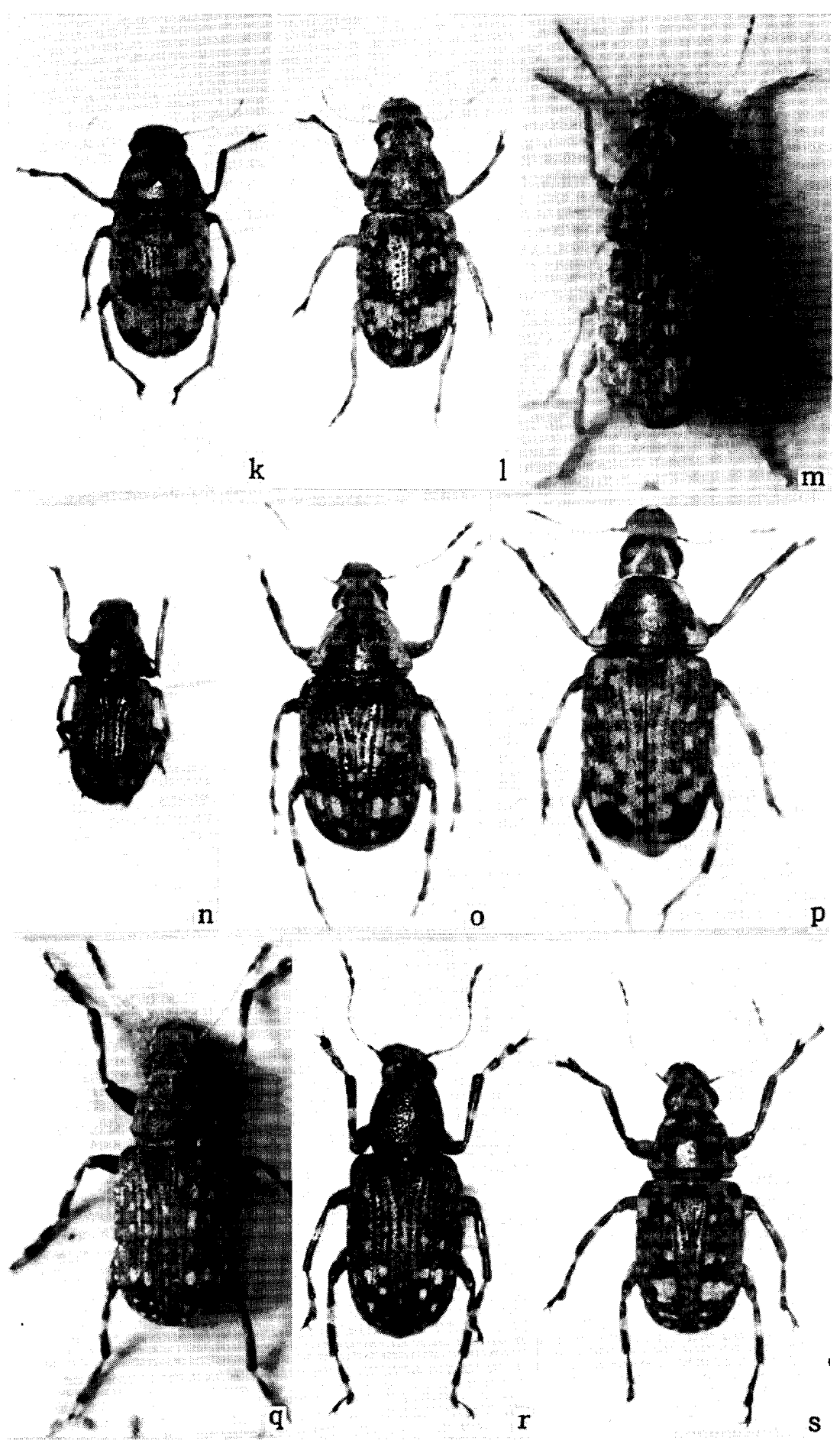